\title{
Changing chain: past, present and future of the Scotia Arc's and Antarctica's shallow benthic communities*
}

\author{
DAVID K.A. BARNES \\ British Antarctic Survey, N.E.R.C., High Cross, Madingley Road, Cambridge, CB3 OET, England. \\ E-mail: dkab@bas.ac.uk
}

\begin{abstract}
SUMMARY: The Scotia Arc links Patagonia to the Antarctic Peninsula. This island chain has changed considerably since Antarctica's geographic and thermal isolation from other land and water masses. Now its rates of air, land and fresh-water climate change are among the highest measured. This review examines work on the shallow water benthos of this region in the context of climate change. In summer, primary productivity is as intense as anywhere, whilst in winter the water reaches unprecedented clarity. Suspension feeders may eat for just a few months but others feed all year. Growth and reproduction are up to 50x slower than non-polar rates. Life here is in the slow lane. There is intense summer disturbance from icescour and wave action. This has erased shore zonation and created it below the surface. In contrast to summer disturbance, the winter is among the calmest and most thermally stable environments, when the area is overlain by fast ice. Whilst few animal phyla or species are represented on land, phyletic richness - and in some groups species richness - rivals that of tropical regions. Data showing clines in benthic richness at several taxonomic levels across the Patagonia-South Georgia-Signy Is.-Adelaide Is. chain and 50 years of ice-sheet retreat are presented.
\end{abstract}

Keywords: polar benthos, zonation, metabolism, suspension-feeding, growth, reproduction.

RESUMEN: UNA CADENA CAMBIANTE: PASADO, PRESENTE Y FUTURO DE LAS COMUNIDADES BENTÓNICAS SOMERAS DEL ARCO DE SCotia y ANTÁRTIDA. - El Arco de Scotia conecta la Patagonia con la Península Antártica. Esta cadena de islas ha cambiado considerablemente desde el aislamiento geográfico y térmico de la Antártida respecto de otras masas de agua y tierra. Actualmente, esta área tiene las tasas de cambios climáticos más elevadas, tanto en aire, tierra y aguas continentales. En esta revisión, se examinan los estudios en las comunidades bentónicas de aguas someras en el contexto del cambio global. La productividad primaria es, durante el verano, tan intensa como en otras áreas, mientras que en invierno las aguas alcanzan una claridad sin precedentes. Los suspensívoros pueden alimentarse por apenas unos pocos meses, pero otros se alimentan durante todo el año. El crecimiento y la reproducción son hasta 50 veces más lentos que en los organismos no polares. La vida aquí está en el "carril lento". Durante el verano, existe un disturbio intenso debido al raspaje del hielo y la acción de olas. Estos factores han eliminado la zonación costera y la generaron debajo de la superficie del agua. En contraste al disturbio de verano, el invierno está entre los ambientes más calmos y térmicamente estables, cubierto por la banquisa de hielo. Mientras que sólo unos pocos phyla o especies animales están representados en tierra, la riqueza filética y en algunos grupos la riqueza específica, equipara la de las regiones tropicales. Se presentan datos evidenciando gradientes en la riqueza bentónica en varios niveles taxonómicos a través de la cadena Patagonia - Islas Georgias del Sur - Isla Signy - Isla Adelaida, además de 50 años de retracción glaciaria.

Palabras clave: bentos polar, zonación, metabolismo, suspensívoros, crecimiento, reproducción.

\section{ENVIRONMENTAL CHARACTERISTICS}

When the ancient supercontinent of Gondwana disintegrated and the fragments drifted apart to form

*Received March 4, 2004. Accepted March 21, 2005. continents, Antarctica became very isolated over the geographic south pole. From its former near-subtropical forests, Antarctica has become the coldest, windiest, driest and highest continent that is almost entirely covered with ice sheets several kilometres thick. The Circumpolar Current that developed in 


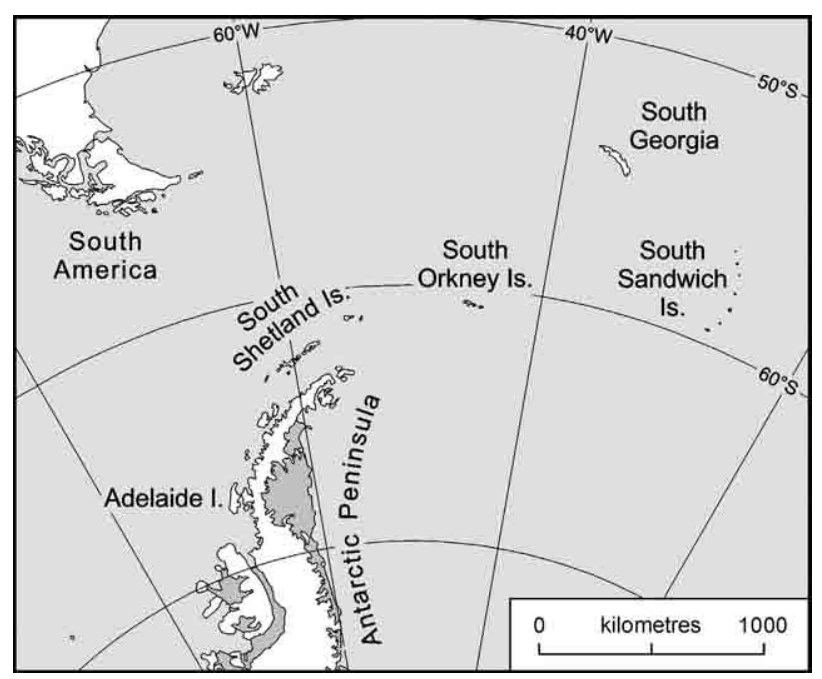

FIG. 1. - The Patagonia-Scotia Arc-Antarctic Peninsula region of the South Atlantic and Southern Ocean. The major study islands discussed are named.

the deep basins surrounding the cooling continent and the Polar Frontal Zone (PFZ) became a major oceanic barrier between the southern parts of the Atlantic, Indian and Pacific Oceans and the Southern Ocean. At its narrowest point it covers almost 10 degrees of latitude $\left(53-63^{\circ} \mathrm{S}\right)$, which is almost entirely ocean, except for a few small islands and archipelagos. Several of these archipelagos, South Georgia, the South Sandwich Islands and the South Orkney Islands (Fig. 1), are the tips of an almost continuous subsurface mountain chain linking the Andes and the Antarctic Peninsula. These mountains, the Scotia Arc, are the only connection between Antarctica and another continent apart from deep abyssal plains. At the most northerly and ice free (and thus most convenient) parts of the continent, islands such as the South Shetlands have become important centres for science and other anthropogenic activities. Convenience aside, the Patagonia-Scotia Arc-Antarctic Peninsula has for many reasons become a crucial region of the globe for biological and climatological research.

For examination of nearshore benthic systems, the Patagonia-Scotia Arc-Antarctic Peninsula offers the only possibility for investigating the continuity of trends across latitude at southern high latitudes. It also represents the mostly likely point for invasions of terrestrial and marine habitats. Although some parts of the Scotia Arc, the South Sandwich Islands, are very poorly known (Baker et al., 1964; Holdgate and Baker, 1979), the Scotia Arc and Antarctic Peninsula region have increasingly become hotspots for cold water research. In the 1970s, much of the ground- breaking polar research was focused at McMurdo Sound in the high Antarctic (e.g. Dayton et al., 1970; 1974). The last decade, however, has seen a proliferation of science in the west Antarctic region, including significant progress in the understanding of colonisation (e.g. Rauschert, 1991), growth (e.g. Klöser et al., 1993), larval development (Peck, 1993), reproduction (e.g. Brêthes et al., 1994), feeding (e.g. Barnes and Clarke, 1995), food availability (Clarke and Leakey, 1996), metabolism (e.g. Ahn and Shim, 1998) and specific dynamic action (e.g. Robertson et al., 2001) in the nearshore benthic environment. Important discoveries of ice shelf disintegration (Doake and Vaughan, 1991), high shelf benthic richness (Barnes and Brockington, 2003), great age and records of atomic bomb tests in animal shells (Peck and Brey, 1996), warming of air (King and Harangozo, 1998) and lake temperatures (Quale et al., 2002) have also focused on western Antarctica. In this review many features of the environment and shallow benthic faunas are compared, such as disturbance, zonation, recruitment, diversity and mortality along this link between the continents. Of crucial importance and background to such discussions is the context of the southern polar environment and how it contrasts with elsewhere.

The relative positions and amounts of land and water in the south and north polar regions are very different; at Scotia Arc latitudes the southern hemisphere is virtually all water, whereas it is nearly all land in the northern hemisphere. At $55-70^{\circ} \mathrm{N}$ Subarctic and Arctic seas have massive fresh water input over summer periods as major rivers discharge on all sides from the surrounding continents. The ocean around the Scotia Arc is virtually all fully saline (Antarctica has no rivers). Some of the Scotia Arc islands (e.g. the South Sandwich Archipelago) may be young but the region is old, whilst the entire Arctic environment is young. There are, however, many similarities between the Scotia Arc region of Antarctica and equivalent northern hemisphere latitudes, particularly in terms of climate. For matched latitudes there is the same light climate, becoming more seasonal polewards. This imparts a strong seasonal influence on sea surface temperatures, fast-ice (frozen sea surface) formation and breakup, disturbance and primary productivity (and therefore, secondary productivity). Sea surface temperatures change abruptly across the PFZ with those south of it, typically reaching nearly $-2^{\circ} \mathrm{C}$ in winter and barely $+2^{\circ} \mathrm{C}$ in summer (Table 1 ). In addition to the glaciations, the relatively long period of cold southern polar sea temperatures has removed much of 
TABLE 1. - Comparison of marine environments from Patagonia to the Antarctic Peninsula in terms of physical, biological, climatic and anthropogenic factors of change. Decreased ozone is shown as ' $\Downarrow \mathrm{O}_{3}$ '.

\begin{tabular}{|c|c|c|c|c|c|}
\hline factor & Patagonia & South Georgia & South Orkneys & South Shetlands & Antarctic Peninsula \\
\hline sea temp & $0^{\circ} \mathrm{C}$ to $12^{\circ} \mathrm{C}$ & $-2^{\circ} \mathrm{C}$ to $>4^{\circ} \mathrm{C}$ & $-2^{\circ} \mathrm{C}$ to $2^{\circ} \mathrm{C}$ & $-2^{\circ} \mathrm{C}$ to $2^{\circ} \mathrm{C}$ & $-2^{\circ} \mathrm{C}$ to $4^{\circ} \mathrm{C}$ \\
\hline ice scour & $\begin{array}{l}\text { occasional around } \\
\text { glaciers }\end{array}$ & $\begin{array}{l}\text { occasional around } \\
\text { glaciers }\end{array}$ & $\begin{array}{l}\text { seasonal major } \\
\text { factor }\end{array}$ & $\begin{array}{l}\text { seasonal major } \\
\text { factor }\end{array}$ & $\begin{array}{l}\text { seasonal major } \\
\text { factor }\end{array}$ \\
\hline fast ice & rare & $\begin{array}{l}\text { occasional, } \\
\text { short period }\end{array}$ & $\begin{array}{l}\text { seasonal, up to } \\
9 \text { months }\end{array}$ & $\begin{array}{l}\text { seasonal, up to } \\
8 \text { months }\end{array}$ & $\begin{array}{l}\text { seasonal, } \\
\text { up to } 8 \text { months }\end{array}$ \\
\hline radiation & $\begin{array}{l}\text { seasonal. } \Downarrow \mathrm{O}_{3} \\
\text { for days }\end{array}$ & $\begin{array}{l}\text { seasonal. } \Downarrow \mathrm{O}_{3} \\
\text { for days }\end{array}$ & $\begin{array}{l}\text { seasonal. } \Downarrow \mathrm{O}_{3} \\
\text { for days }\end{array}$ & $\begin{array}{l}\text { seasonal. } \Downarrow \mathrm{O}_{3} \\
\text { for weeks }\end{array}$ & $\begin{array}{l}\text { seasonal. } \Downarrow \mathrm{O}_{3} \\
\text { for weeks }\end{array}$ \\
\hline climate change & $\begin{array}{l}\text { glacial retreat, } \\
\text { air temps }\end{array}$ & $\begin{array}{l}\text { glacial retreat, } \\
\text { air temps }\end{array}$ & $\begin{array}{l}\text { highest lake } \\
\text { warming, air temps }\end{array}$ & air temps & $\begin{array}{l}\text { ice shelf changes, } \\
\text { air temps }\end{array}$ \\
\hline organism invasions & terrestrial/ marine & terrestrial / lake & terrestrial & terrestrial/ marine? & terrestrial \\
\hline persistent debris & abundant & abundant & common & common & rare \\
\hline tourism and ship traffic & high & high & low & moderate & low \\
\hline science presence & moderate & low & low & high & low \\
\hline
\end{tabular}

the terrestrial and intertidal biota. This, and the relative constancy of this low-temperature environment, have left biota which are highly stenothermal and an austral fauna with a strong pattern of temperature-dependent biogeography (Peck, 2002; Pörtner, 2002a,b,c). The influence of temperature in the polar realm has been of fundamental interest for half a century and even now its effect on fertilisation or enzyme kinetics (Vetter and Buchholz, 1998) and rates of protein synthesis (Fraser et al., 2002) have become important topics. Clarke (1988) described the seasonal pattern of sea surface temperature at Signy Island as typically being a long period at $-1.85{ }^{\circ} \mathrm{C}$ followed by a sharp rise to positive temperatures, then a few months later a sharp fall back to $-1.85{ }^{\circ} \mathrm{C}$. Sahade et al. (1998) have found this pattern to be little different in the South Shetland Islands, and indeed it is similar further down the Antarctic Peninsula at $68^{\circ} \mathrm{S}$ (Adelaide Island). In contrast, south of the Antarctic Peninsula, around the continental margins, the annual change in sea surface temperature has been reported to be as little as a tenth of a degree (Dayton et al., 1970). Therefore, Antarctic sea temperatures, compared with those in Patagonia and elsewhere (even the high arctic), are characterised by depressed levels and relative constancy.

\section{DISTURBANCE}

All environments experience disturbance, but the frequency, scale and patchiness of events differ enormously. It is not, however, merely the intensity of destruction which dictates the effect on the biota: the capability of communities to recover governs the diversity and structure of ecosystems. Forests experience small-scale (in time and space) events ranging from tree falls to massive land slides (Garwood et al., 1979; Borkaw, 1985). Nearshore marine environments are typically exposed to chemical, biological and physical disturbance. In coastal water this is often from sedimentation, fresh water runoff, pollution, anoxia or currents and wind-driven wave action. Of these, currents and wave action are likely to be most important in the Scotia Arc region. This sort of disturbance ranges from the smallest ripples, which are only likely to effect meiofauna, to benthic storms, hurricanes and tsunamis. The average wind speed and wave height is reasonably predictable across the globe by latitude (Fig. 2A,B): the most heavily disturbed latitudes are those at the level of the Scotia Arc.

Shallow seas also experience a wide range of mechanical disturbance, incuding bioturbation by organisms, bashing by drift logs (Dayton, 1971), digging by Gray whales (Nerini and Oliver, 1983) and hurricanes (Wulff, 1995). None of these agents of disturbance are as severe in either impact force or frequency as ice scour, which like wave height is predictable to some extent by latitude (Fig. 2C). The polar and sub-polar regions occupy a major proportion of the globe (nearly a third), but ice scour also occurs adjacent to glaciers at lower latitudes (Pugh and Davenport, 1997). Nevertheless, in terms of non-anthropogenic disturbance an averaged mean 


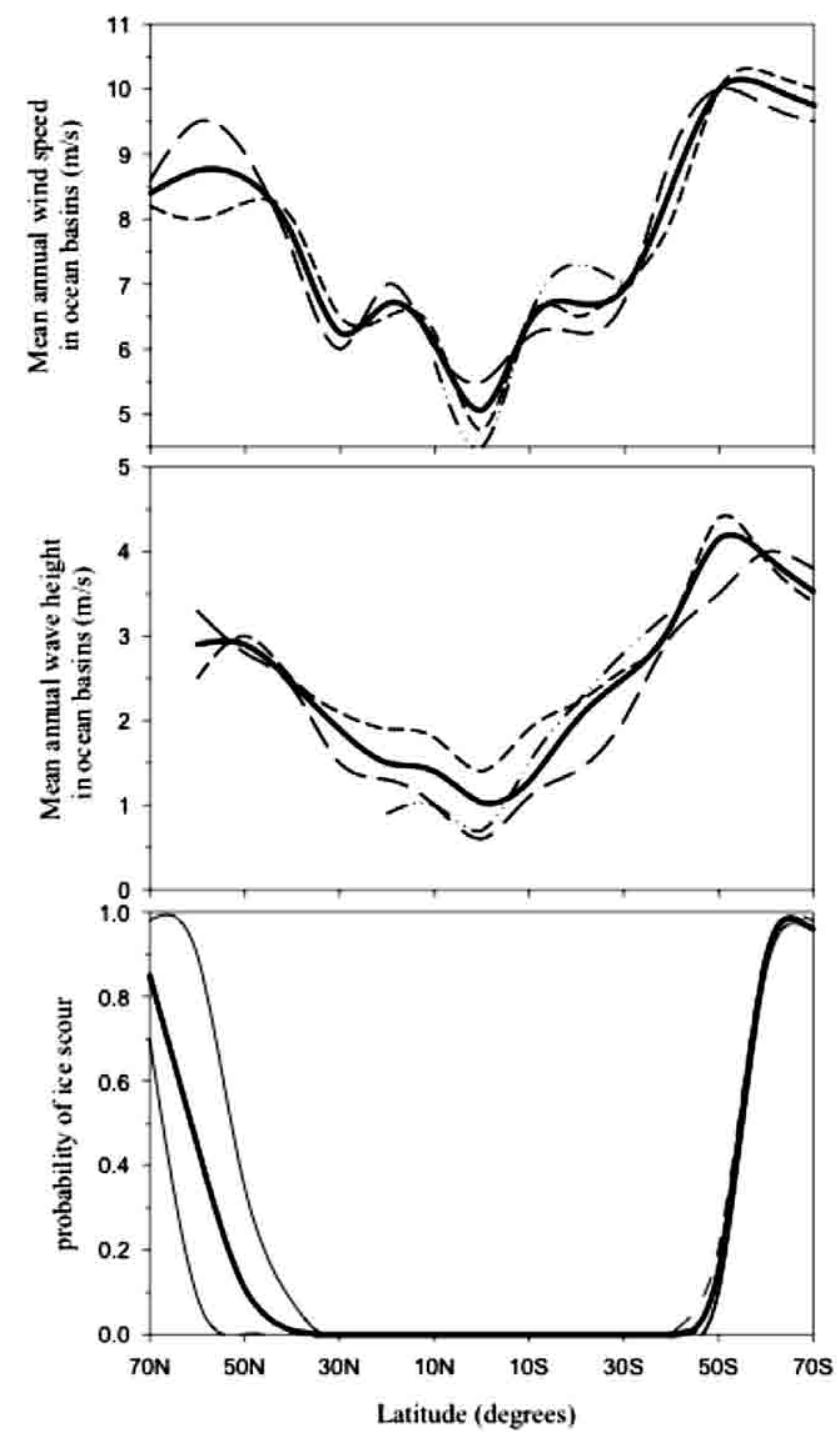

FIG. 2. - Shallow water disturbance with latitude and ocean basin. Mean surface wind speed and wave height from Barnes (2002a) drawn from data in Bentamy et al. (1996); solid line is mean across different oceans. Ice scour data from satellite imagery of floating ice prevalence.

across latitude is likely to show massive levels at polar latitudes compared with anywhere else. In periods of open water billions of pieces of floating ice collide with the sea floor, almost denuding the intertidal zone around an entire continent (Hedgepeth, 1969; Shabica, 1972). Below the littoral bigger icebergs are able to hit (Fig. 3A) - the biggest scrape the bottom at several hundred metres (Lien et al., 1989; Gutt et al., 1996) and are amongst the most destructive natural forces (Dayton, 1990). In the Scotia Arc one of the major influences of icescour on hard substrata is a marked pattern of sublittoral zonation (Shabica, 1972; Zamorano, 1983; Gallardo, 1987; Gambi et al., 1994; Barnes 1995a; Nonato et al., 2000; Gutt, 2001; Barnes and Brock- ington, 2003). The same is also true at many Arctic and Subarctic localities (Ellis and Wilce, 1961; Bolton, 1983; Dowdswell et al., 1993; McCook and Chapman, 1997; Conlan et al., 1998). In mud and silt ice, gouging can even wipe out most of the meiofauna (Peck et al., 1999, Lee et al., 2001a) and resuspend huge volumes of sediment (Rearic et al., 1990). These plough furrows and other ice scour features have been preserved in rock, giving important clues to pre-present aquatic ice patterns and processes (Dionne, 1977; Vogt et al., 1994). The recolonisation time in sediments begins in days, with the more mobile forms, particularly scavengers, returning to feast on the previous destruction (Peck et al., 1999; Lee et al., 2001a,b). Thus, as theorised for deep sea environments (Dayton and Hessler, 1972; Grassle and Sanders, 1973), this disturbance promotes wider scale diversity by increasing surface heterogeneity (Fig. 3B) and the dominance of fauna from place to place (Gutt and Piepenburg, 2003). On hard substrata too, encrusting, competitively-dominant species are prevented from monopolising space by periodically being wiped out (Barnes, 2002a). Poorly ranked competitors (usually pioneers) are often highly abundant in shallow polar habitats, as can also happen at some lower latitude sites promoted by disturbance (Dayton, 1971; Paine, 1979; Karlson, 1983) or keystone species abundance (Paine, 1974). In the Patagonia-Scotia Arc-Antarctic Peninsula region there is likely to be a trend of increased levels of ice scour with latitude, but any signal from such a cline would be complex for several reasons:

The latitude of the PFZ, and therefore freezing water, varies in time and space. The ANDEEP (Fütterer et al., 2003) and LAMPOS (Arntz and Brey, 2003) cruises of the Polarstern have, for example, collected data suggesting the PFZ to occasionally be south of South Georgia. If this is the case, the PFZ may wander hundreds of miles in the South Georgia region.

Complexity is also generated by other forms of disturbance, such as wave action (Fig. 2B), ice-foot and anchor ice formation, also changing with latitude.

The prevalence and duration of freezing surface waters (fast ice) increases with latitude. When fastice forms it effectively locks up icebergs so that they are immobilised, reducing scouring to already grounded ice, and even this to only the location where they are.

Anchor ice (formed by supercooled water nucleating around organisms or objects) is rare in the Sco- 

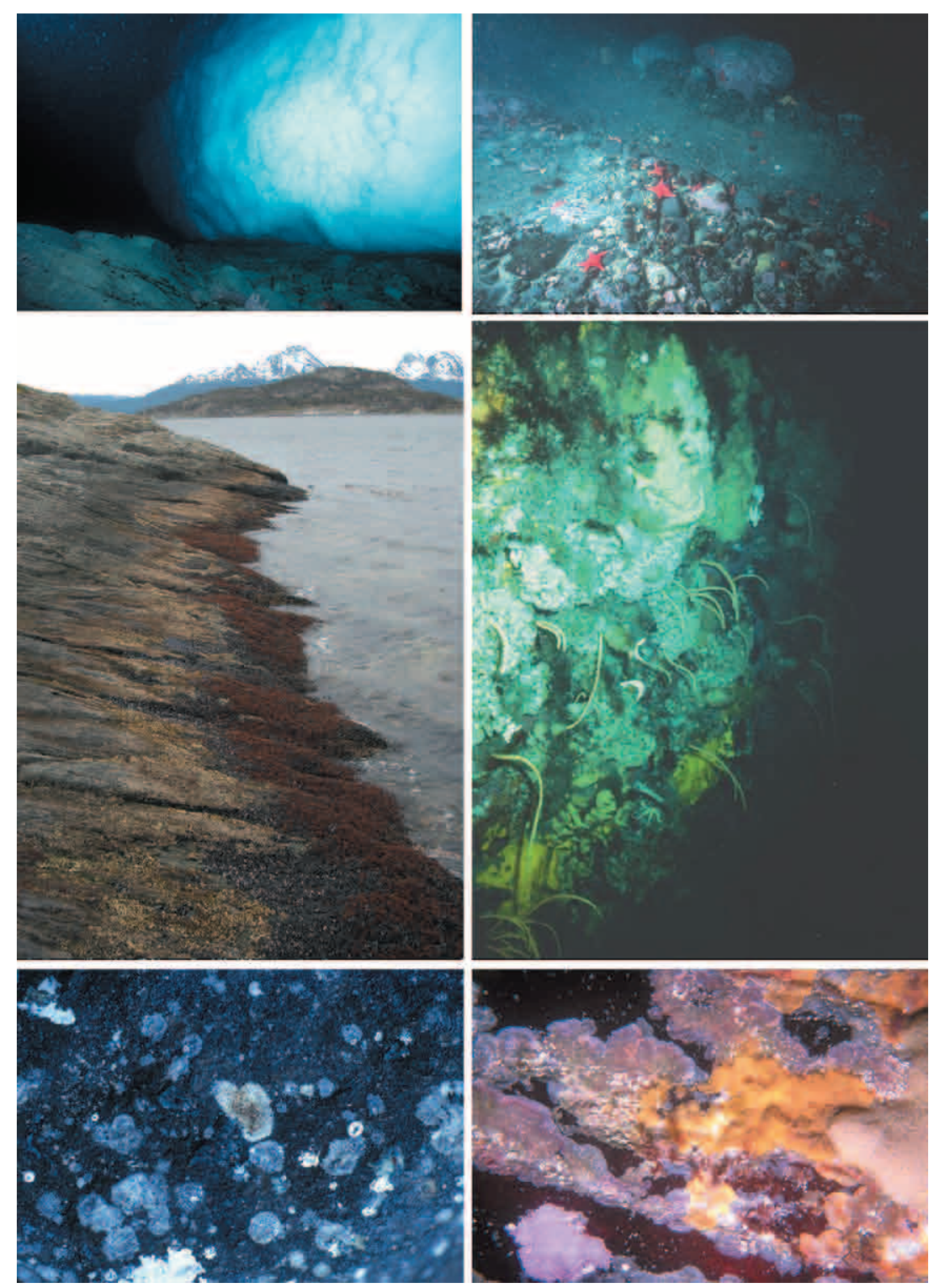

FIG. 3. - Disturbance and colonisation. Ice in the process of scouring the seabed (top left); ice scour path left after iceberg has scraped the seabed (top right); southernmost shore zonation in Tierra del Fuego (middle left); rich benthos on a wall at 20 m. Signy Island (middle right); first year colonisation on a boulder at Adelaide Island (bottom left); colonisation after $\sim$ a decade (bottom right).

tia Arc or along the Antarctic Peninsula, and even in the high Antarctic below 30 m (Dayton et al., 1970; 1974). Much of Antarctica's coastline lies at 67-72 ${ }^{\circ} \mathrm{S}$, but we still know little of the relative balances of disturbance and community structuring at these latitudes. Only at the Vestfold Hills and Adelaide Island has shallow shelf sea bed and fauna even been studied in moderate detail in the context of ice disturbance (Kirkwood and Burton, 1988; Tucker, 1988; Barnes and Brockington, 2003). There is, however, no littoral or even shallows around much of the high Antarctic, as floating ice sheets extend out from the continent. In the SE Weddell Sea the only 'shallows' are sea-mounts rising to within $100 \mathrm{~m}$ of the surface.
Ice is clearly one of the most severe natural disturbance events. Only in recent years, however, has the impact of anthropogenic disturbance-particularly fishing - begun to be evaluated and realised. Fishing has massively changed benthic (and other) ecosystems across the globe by systematically removing the uppermost trophic level (Jackson et al., 2001). In warm waters sharks and large predatory fish, such as tuna, have been gradually been reduced to smaller populations of smaller fish (Myers and Worm, 2003), with ultimately a smaller ecological role. These authors suggest that large predatory fish have been reduced to just $10 \%$ of their number, causing catastrophic changes cascading along trophic levels. In 
the Scotia Arc this is now happening to the Patagonian Toothfish Dissostichus and the commercially fished squid populations (Collins et al., 2003). In the case of these Southern Atlantic and Southern Ocean fisheries, as with whales, the problem is acute, as adults take a long time to grow and mature. Furthermore, the fishing methods have resulted in by-catches of seabirds and have been crippling populations of another top predator-albatrosses (Schiavini et al., 1998). Previously the Southern Ocean, particularly around the Scotia Arc, was the centre for one of the largest scale changes of an ecosystem. Over just a few decades the large populations of the most massive animals ever to have occurred on earth were reduced to near ecological extinction. In size-successive order man removed the Blue, Fin, Sei and other baleen whales from the ecosystem - their bones lie scattered around many bays of the Scotia Arc islands (e.g. South Georgia and Signy Island). It seems that even the scale of the reduction of the great whales themselves is still being underestimated (Roman and Palumbi, 2003).

The effects of demersal fishing in some ways mimic those of ice scour. Some areas are being 'scoured' by trawls many times a year (Collie et al., 2000, Thrush and Dayton, 2002), though this is rare within the Scotia Arc. The type of destruction resembles ice scour in many ways, such as in the type, effect and frequencies involved. Acoustic methods are increasingly being used to evaluate the impact of fishing on benthic communities and this method is likely to be an increasingly powerful tool for investigating polar ice scouring. In the Patagonia-Scotia Arc-Antarctic Peninsula, ice is probably the major structuring influence to coastal benthic communities above $\sim 100 \mathrm{~m}$ depth, and in some areas even below this (Gutt, 2001). In the intertidal this is principally mediated by ice-foot encasement during the winter and by ice-scour during summer open-water periods (seasonally in Patagonia (Fig. $3 \mathrm{~A}, \mathrm{~B})$ ). In the shallow subtidal, ice-scour starts overtaking wave action as of most influence at about $52-56^{\circ} \mathrm{S}$ and anchor ice likewise starts becoming the most important influence south of 73-75 ${ }^{\circ} \mathrm{S}$ (Barnes and Brockington, 2003). In deeper polar water it is clear that scouring occurs commonly (in places) even at several hundred metres depth, in both the Antarctic and the Arctic (Gutt et al., 1996; McCook and Chapman, 1997; Gutt and Starmans, 2001). Therefore, ice effects have pronounced clines with latitude, bathymetry and season, but are most apparent in the strong zonation created.

\section{ZONATION}

Zonation has for more than a century been an important concept for understanding distributions of organisms. Many environmental gradients exist in space and time but those that marine biologists particularly associate with zonation are tidal, geographical, topographical and exposure. Nowhere is this more obvious than on temperate shores as a clear series of 'belts': superabundance of particular animals, algae or lichens are obvious across a vertical plane spanning just a few meters. On the southernmost shores of South America, Africa and Australasia littoral zonation is striking, yet around the Antarctic and high Arctic coastlines this banding disappears (Dayton, 1990). In the Atlantic, Tristan da Cunha $\left(37^{\circ} \mathrm{S}\right)$, Gough $\left(41^{\circ} \mathrm{S}\right)$ and the Falkland/Malvinas Is. $\left(51^{\circ} \mathrm{S}\right)$ are amongst the most southerly islands. On these shores littoral zonation is clear amongst algae and macrofauna (see de Vil-

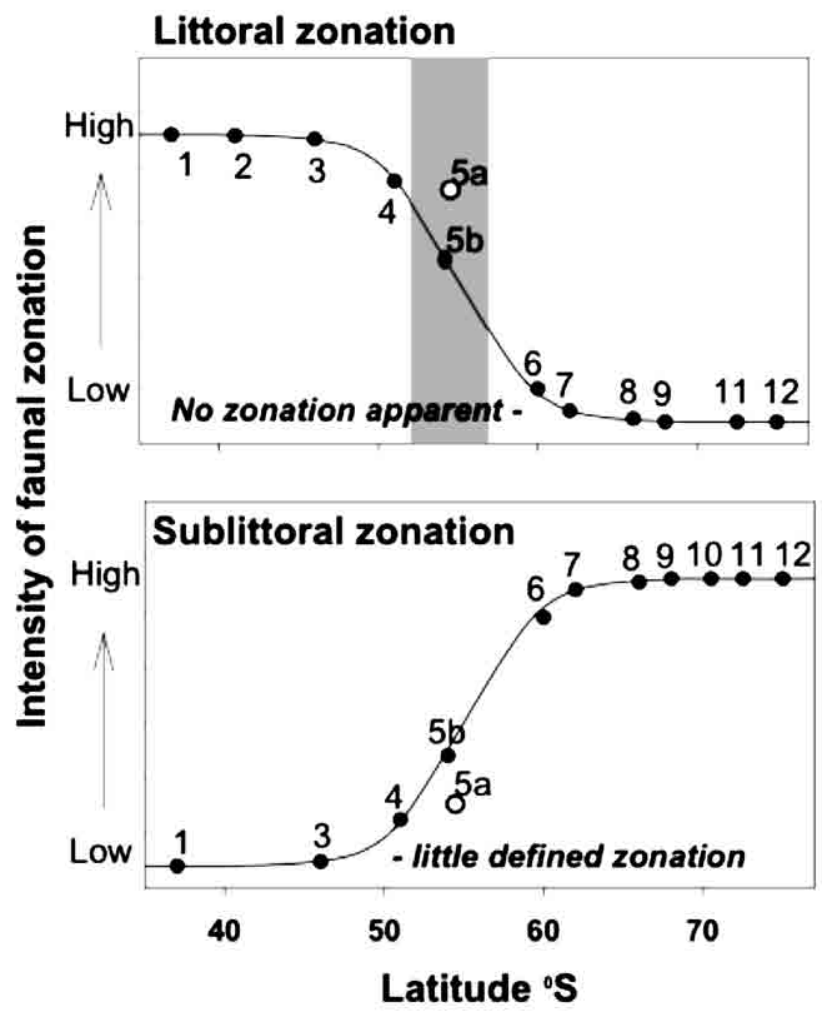

FIG. 4. - Intensity of faunal zonation with latitude in the littoral (upper) and sublittoral (lower). The position of the Polar Frontal Zone is shown as a grey shaded bar. Schematic diagram modified from Barnes and Brockington (2003) suggesting a change of intensity of zonation based on the strength of littoral and sublittoral macrobiota patterns at sites at latitudes indicated by 1 . Tristan da Cunha, 2. Gough Is., 3. Prince Edward Archipelago, 4. Falkland Islands, 5a. Ushuaia (Tierra del Fuego), 5b. South Georgia, 6. Signy Island, 7. South Sandwich Archipelago, 8. Haswell Is., 9. Adelaide Is., 10. Weddell Sea seamount at $71^{\circ} \mathrm{S}, 11$. Vestfold Hills, 12. McMurdo Sound. 
liers, 1976). Around the margins of the Polar Frontal Zone, though, there is a dramatic change: the only sign of shore zonation is the banding of macroalgae. This is largely the case in the Subantarctic islands of the Prince Edward archipelago, Kerguelen and South Georgia (de Villiers, 1976; Pugh and Davenport, 1997). Beyond these latitudes, in the South Sandwich, South Orkney and South Shetland archipelagos, even macro-algae are absent from shores. As zones are entirely biologically defined, that is they are largely the visible patterns of a few such dominant species (Underwood and Kennelly, 1990), the phenomenon of zonation in the littoral disappears south of about $54^{\circ} \mathrm{S}$ - except at the southern tip of South America. The most southerly shores around Cape Horn at about $55^{\circ} \mathrm{S}$ are permanently north of the PFZ and do show (reduced) faunal and algal zonation (Fig. $3 \mathrm{C})$. Thus, there is a cline in the strength of zonation with latitude, which can be seen by comparing shores of islands from the South Atlantic to those along the Antarctic Peninsula (Fig. 4).

Increased levels of floating ice, the scouring that this causes, and winter freezing are thought to be the driving factors behind the disappearance of abundant littoral macrobiota and zonation. For decades it was considered that life was virtually absent from the Antarctic littoral zones, but there are a fewmainly marine-species that colonise during summer open-water periods (see Hedgepeth, 1969; Shabica, 1972; Barnes et al. 1996; Kim, 2001; Barnes and Brockington, 2003). However, ice scour, primarily responsible for the reduction of shore biota and zoning, starts becoming a major structuring force in the sublittoral at similar latitudes. Only fast-growing pioneer species (a few gastropods, bivalves, tubicolous polychaetes, encrusting bryozoans and hydroids) are found in the top 5-10 m on hard rocky bottoms at Signy Island in the South Orkney Archipelago $\left(60^{\circ} \mathrm{S}\right)$ (Barnes, 1995b). The different faunas between $25 \mathrm{~m}$ (Fig. 3D) and $6 \mathrm{~m}$ at Signy Island are, however, apparent even in the differential species recruiting to newly available substrata (Stanwell-Smith and Barnes, 1997). Experimental panels immersed for nearly 2 years at $6 \mathrm{~m}$ at Signy Island were only colonised by the few pioneers (spirorbid worms and a few species of bryozoans) that are typical of encrusting communities at that depth. Similar panels immersed at the same place for the same period but at $25 \mathrm{~m}$ revealed a much richer colonising fauna. In the upper-most islands of the Antarctic Peninsula region, zonation is a prominent feature, and has been documented from a variety of islands, especially around the South Shetland Archipelago $\left(62^{\circ} \mathrm{S}\right)$. As with temperate shore zonation, this probably takes the form of a series of slightly differing species distributions, but 3-4 zones are characteristically described, based on the distributions of the most abundant species. One of the earliest descriptions (from the South Shetland Archipelago), by Gruzov and Pushkin (1970), trisplit the shallow subtidal into an upper surf zone, a middle kelp zone and a deeper $(15-30 \mathrm{~m})$ fauna zone. More detailed accounts of biota horizons in the shallow waters around King George Island have been given by Zielinski (1981), Rauschert (1991), Klöser et al. (1993), Arntz et al. (1994), Arnaud et al. (1998), Jazdzewski (1998), Sahade et al. (1998), and most recently by Nonato et al. (2000) and Bromberg et al. (2002). The upper zone (0-4 m), though variable from place to place, seems to be mainly depauperate of fauna (apart from amphipods) and comprises the algae Desmarestia, Himantothallus and Leptsomia. Below this, to about 15-18 m polychaetes, the limpet Nacella concinna, serolid isopods and the bivalve Laternula elliptica become abundant. In the deeper zones to $25 \mathrm{~m}$ and beyond the fauna becomes richer and resembles a typical shallow-water Antarctic Peninsula fauna, e.g. the echinoid Sterechinus neumayeri, the nemertean Parborlasia corrugata and the isopod Glyptonotus antarcticus, among others. Meiofaunal patterns seem to be similar to those in the macrofauna (increases in abundance and diversity) with respect to depth (Skowronski et al., 1998; Vanhove et al., 2000; Lee et al., 2001a,b).

Though less well described, the benthic zonation appears to be more delineated at the Palmer Archieplago (Zamorano, 1983) and the Haswell Islands $\left(66^{\circ} \mathrm{S}\right)$ (Propp, 1970) and at Adelaide Island (Barnes and Brockington, 2003). At Adelaide Island Barnes and Brockington (2003) report that the trilevel zonation can even be distinguished by characteristics within populations of single species: the size of Sterechinus neumayeri varies significantly with depth. Furthermore, species such as $S$. neumayeri, and other grazers (e.g. Nacella concinna), can not only create zonation patterns by their own differential abundance but by their feeding intensify them through removal of recruits. Strong zonation has been found at similar depths at other higher latitude sites around the Antarctic continent shelf (Gallardo 1987), or more specifically the Vestfold Hills (Kirkwood and Burton, 1988), Terra Nova Bay (Cat- 
taneo-Vietti et al., 2000) and McMurdo Sound (Dayton et al., 1970; 1974; Dayton, 1979; Miller and Pearse 1991). The vertical zonation absent in the littoral zone south of the PFZ is therefore quite apparent in the shallow sublittoral and increases as an opposite trend to decreasing shore patterns (Fig. 4). A number of authors have, however, reported distinct sublittoral zonation along temperate Pacific shores, particularly along the Chilean fjords and Californian coast.

Ellis and Wilce (1961), and others since, have reported equivalent zonation patterns from the high Arctic. The littoral macrofauna and zonation patterns do become reduced with latitude, though there are still quite a number of species on some shores at $77-79^{\circ} \mathrm{N}$ (Spitsbergen) (Weslawski et al., 1993). Both in the littoral and sublittoral, Arctic biota have strong additional forces of zonation. Run-off from surrounding continents, especially large inputs of fresh water, localised pollution and sedimentation (Holte et al., 1996) or anoxia (Kvitek et al., 1998) contribute substantially to faunal vertical distributions. Changes in zonation with latitude (mediated by ice scour) probably occur up coastlines into the Arctic as well as along the Patagonia-Scotia Arc. Zonation is clear in the high Arctic sublittoral (Dayton, 1990), though equivalent changes seem to occur at a much higher boreal (than anti-boreal) latitude. As in the southern polar region, these patterns in the sublittoral are due to the frequency of disturbance versus the potential of biota to colonise. Settlement and recruitment was therefore a key feature for the understanding of nearshore benthic community structure, yet until 1991 (when both Pearse and Pearse, and Rauschert reported studies), Dayton and Oliver's now famous (1977) experiment at McMurdo Sound was the only such study reported from the entire Southern Ocean.

\section{RECRUITMENT}

For a long time since the pioneering reproductive studies undertaken by Thorson and their wider interpretation (Mileikovsky, 1971), the idea of many polar taxa using pelagic larvae was against a strong paradigm. A couple of decades later it seemed that some taxa did not follow Thorson's rule (Pearse et al., 1991; but see Arntz and Gili, 2001). Even in remote archipelagos like the South Orkney Islands, pelagic larvae from a wide range of taxa can be common (Stanwell-Smith et al., 1998). Pelagic lar-

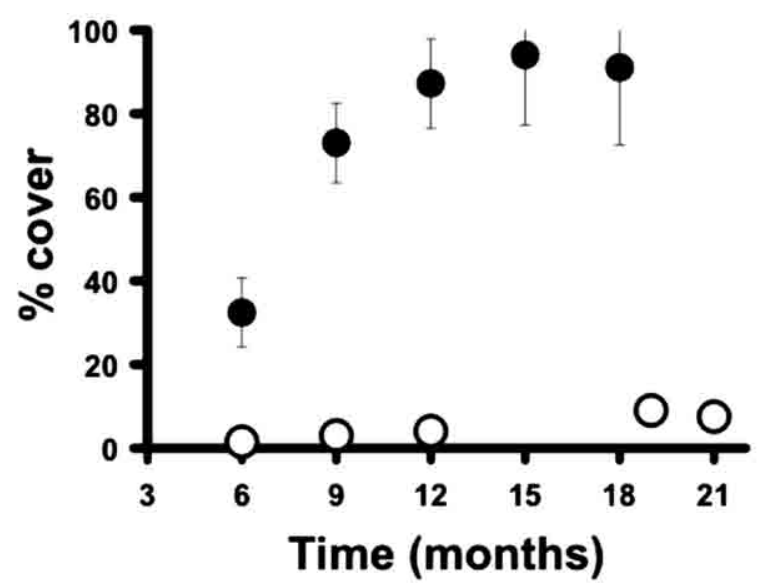

FIG. 5. - Coverage of artificial substrata (settlement panels) in temperate/tropical localities (filled symbols) vs southern polar localities. Adapted from Stanwell-Smith and Barnes (1997).

vae may, however, be quite rare in large areas of the Southern Ocean, such as across the Weddell Sea (unpublished ANDEEP III cruise data). The timing, duration, abundance and mortality of recruits was completely unknown in the southern polar region before Dayton (1989) reported some strange recruitment patterns in the Ross Sea. This experiment had been running for about a decade and a rich fauna, with respect to cheilostome and cyclostome bryozoans, had colonised the panels (Moyano, 1984). Periodic macroscopic observation by divers had suggested almost no recruitment for a number of years followed by a massive recruitment later on in the experiment. This may, indeed, be evidence of considerable interannual variation, as suggested by Dayton (1989), but there are other interpretations. Early examination was by divers only, so it is not surprising that they were unable to see much because many pioneer species are small and translucent. Furthermore, for a number of years the panels were not examined at all, so while strong interannual variation in recruitment may have occurred, we cannot be certain that recruitment was more gradual, as has been measured elsewhere. In the same year the first of a number of settlement and recruitment studies in the Patagonia-Scotia Arc-Antarctic Peninsula were published. At $46^{\circ} \mathrm{S}$ López-Gappa (1989) showed that benthic recruitment in Magellanic shallow waters closely resembled that of the better-studied northern Atlantic with respect to space occupied, richness and other obvious factors. The first study in the Antarctic Peninsula region revealed the presence and importance of relatively fast-growing ascidians in early community development (Rauschert, 1991). Two back-to-back two-year studies (Barnes, 1996; 
TABLE 2. - Recruitment to benthic environments, experiments with artificial substrata in the Scotia Arc and Antarctic. Two values for species richness and duration refer to the different sources given above.

\begin{tabular}{|c|c|c|c|c|c|}
\hline factor & Patagonia & South Orkneys & South Shetlands & Antarctic Peninsula & high Antarctic \\
\hline source & $\begin{array}{l}\text { López Gappa, 1989; } \\
\text { Barnes, unpublished }\end{array}$ & $\begin{array}{l}\text { Barnes, 1996; } \\
\text { Stanwell-Smith and } \\
\text { Barnes, } 1997\end{array}$ & Rauschert, 1991 & Bowden, unpubl. & $\begin{array}{l}\text { Moyano, 1984; } \\
\text { Dayton, 1989; } \\
\text { Arntz et al. unpub. }\end{array}$ \\
\hline$\%$ cover & $75 \%$ & $2-10 \%$ & $>10 \%$ & $40-80 \%$ & variable by year $(<5 \%)$ \\
\hline species richness & 24 species, 19 species & 22 species, 23 species & low & moderate & 46 species \\
\hline diversity & moderate & low & low & low & moderate \\
\hline $\operatorname{taxa}$ & $\begin{array}{l}\text { polychaetes, } \\
\text { bryozoans, ascidians }\end{array}$ & $\begin{array}{l}\text { polychaetes, } \\
\text { bryozoans, ascidians }\end{array}$ & $\begin{array}{l}\text { polychaetes, } \\
\text { bryozoans, ascidians }\end{array}$ & $\begin{array}{l}\text { polychaetes, } \\
\text { bryozoans, sponges, } \\
\text { ascidians }\end{array}$ & $\begin{array}{l}\text { polychaetes, } \\
\text { bryozoans }\end{array}$ \\
\hline duration & $\begin{array}{l}9 \text { months } \\
4 \text { months }\end{array}$ & $\begin{array}{l}21 \text { months } \\
21 \text { months }\end{array}$ & 3 years & 2 years & $\begin{array}{l}10 \text { years } \\
3 \text { years }\end{array}$ \\
\hline
\end{tabular}

Other southern polar studies include those of Pearse and Pearse (1991), who recorded very little on panels immersed for a year at McMurdo Sound, Davenport and Stevenson (1998), who recorded 3 species on panels at South Georgia, and Gerdes and Klages (unpublished data), who recorded 0 species after 1 year at $670 \mathrm{~m}$ in the Weddell Sea. A further study was set up in the South Shetland Is. more than 4 years ago but remains to be retrieved (Arntz pers. comm.).

Other northern polar studies include those of DePalma (1969), who recorded 8 species (7 at any one time) in Newfoundland, and Schoener et al. (1978), who recorded 8 species ( 8 at any one time) in southern Alaska and 10 species ( 7 at any one time) in Washington. The most recent experiment is the fouling over 2-3 years on Arctic moorings but is yet to be published (Arntz pers. comm.).

Stanwell-Smith and Barnes, 1997) at Signy Island in the South Orkney Islands were the first to report seasonal data. Both studies showed very low levels of colonisation compared to temperate or tropical studies (Fig. 5, Table 2). Whether or not rarity of pelagic larvae contributes to depressing colonisation rates is debatable, as many colonists at low latitudes are those with benthic larvae. Benthic recruitment studies also emphasise the disturbance in shallow water: both Rauschert (1991) and Barnes (1996) lost panels to ice and wave action. Schoener et al. (1978) had shown, despite site and year variability, that latitude was a major factor in explaining recruitment differences in northern hemisphere sites from the tropics to the Subarctic. Although most of Antarctica's coastline lies between 67 and $72^{\circ} \mathrm{S}$, at no site within this latitudinal span had hard substratum recruitment been investigated until recently. The preliminary results of a new shallow water study by David Bowden at Rothera, Adelaide Island, suggests that colonisation rates were low compared to those at low-latitude sites but not nearly to the extent found by the two studies at Signy Island. The depressed colonisation values found by Barnes (1996) and Stanwell-Smith and Barnes (1997) may owe as much to the isolation of the South Orkney Islands as to their polar latitude. If this is true, it contrasts with a lack of strong isolation effects in other austral, but lower-latitude, recruitment studies (e.g. Holmes et al., 1997). To date no large-scale nested studies of recruitment, such as those performed across the Great Barrier Reef (Hughes et al., 1999), have included high latitude sites - this needs to be done to determine the scale at which we can really apportion variability.

Dayton (1989) considered that ice occasionally providing uplift for benthic larvae was important in shallow soft sediment environments in the Ross Sea. Such events might support the interannual variability he and co-workers reported of recruits to panels. Certainly ice patterns do seem to show short 4-8 year patterns as well as those on larger and smaller (seasonal) scales (Murphy et al., 1995). Although many features of sediments have been well studied in the Scotia Arc and Antarctic Peninsula region, little is still known of recruitment to such habitats. Among rooted bryozoans, Winston (1983) found that many of the young colonies had grown from fragments of older ones, so much 'recruitment' was vegetative rather than from sexual origins. In soft sediment habitats, settlement in and invasion of scours, that is the recolonisation of ice denuded areas, has probably been the most studied aspect of recruitment. In deep waters the recruitment of pioneer species to scours has now been well documented in the Arctic (Conlan et al., 1998) and Antarctic (Gutt and Piepenburg, 2003). In shallow waters bimodal distributions of bivalves (e.g. Yoldia eightsi) have been found in well-scoured sediments with entire cohorts missing (Peck and Bullough, 1993). 
Recruitment into soft sediments occurs through both migration in and settlement onto surface muds. Peck et al. (1999) found that recruitment to new scours varied considerably between taxa: the more mobile elements of both macro- and meio-fauna were quickest. Recruitment of meiofauna, as with much of the ecology of this important fraction of the benthos, is poorly known, but work by a few teams is starting to rectify this (e.g. Skowronski et al., 1998; Lee et al., 2001a,b).

\section{DIVERSITY AND RICHNESS}

Half a decade of northern hemisphere work has led to a long and complex argument as to the cause of a 'global' latitudinal cline in biodiversity (see Pianka, 1966; Gray, 2001; Allen et al., 2002). It is frequently referred to as the most recognised diversity pattern, despite the fact that such a trend has never been established in the southern hemisphere (Clarke, 1992). Investigations of global geographic diversity trends in bivalves (Stehli et al., 1967; Crame, 2000) and corals (Stehli and Wells, 1971), for example, have found longitudinal components to be as strong as latitudinal. In gastropods (Roy et al., 1998) and bryozoans (Clarke and Lidgard, 2000) strong pole-ward declines have been established, but their data were restricted to particular northern coasts only. Recently complex but broadly poleward declines have been described in decapods around South America (Astorga et al. 2003) and on North American coastlines (Boschi, 2000). A number of taxa, however, not only show no such decline in the southern hemisphere but even may have raised polar values. These include the brachiopods (Foster, 1974), bryozoans (Hayward, 1995; López Gappa, 2000), pycnogonans (Clarke and Johnston, 2003) and even molluscs (Valdovinos et al., 2003). For such work the coastline of North America conveniently stretches from the tropics to the high Arctic, but the Patagonia-Scotia Arc-Antarctic Peninsula chain has an even greater latitudinal span. For investigation and explanation of large-scale trends in the distribution or characters of organisms, the Patagonia-Scotia Arc-Antarctic Peninsula link offers the best opportunity to evaluate latitude in the southern hemisphere. Early expeditions and collections revealed striking differences between the biota of the southernmost continent and its surrounding ocean, not least the near absence of some taxa, unusual abundance of others, extremely high endemism (see Arntz et al., 1997), minute land fauna and, conversely, gigantism in some marine fauna. Exploring the continuity of such macro-ecological/evolutionary trends has, however, been heavily dominated by work around Europe and North America.

The many confounding problems of using historical data have again placed emphasis on ecological, multiple small-scale sampling across wide latitudinal ranges. For many decades surveys of shallow water benthos have been undertaken from the scientific bases of most nationalities in the Scotia ArcAntarctic Peninsula region (see Arntz et al., 1994; 1997). This information is very patchy in shallow waters. A number of detailed studies have addressed diversity patterns along the Chilean coast (Santelices and Marquet, 1998; Rivadeneira et al., 2002), but few have been undertaken along Argentina and the Falkland/Malvinas (López Gappa 2000) or South Georgia islands and none (to the author's knowledge) in the South Sandwich archipelago. Studies in the South Orkney Archipelago have focused on just one island, Signy (Barnes, 1995a; Barnes et al., 1996), whilst the sublittoral around the South Shetland and Palmer archipelagos in the northern Antarctic Peninsula are probably as well studied as some European and North American coasts (Gruzov and Pushkin, 1970; Zamorano, 1983; Rauschert, 1991; Arnaud et al., 1998; Jazdzewski, 1998; Sahade et al., 1998; Nonato et al., 2000). Antarctic Peninsula sites can be highly speciose, as well as having high biomass and abundance values relative to those in the Arctic or even temperate regions (Brey and Clarke, 1993; Arntz et al., 1997). Some of the highest values recorded have been at Adelaide Island at $68^{\circ} \mathrm{S}$ (Barnes and Brockington, 2003), but vertical surfaces at other locations, such as Signy Island (Fig. 3D), also clearly have high values. At Adelaide island 75 species were found in a total sample area of just $7.5 \mathrm{~m}^{2}$ and 9 species were found in the intertidal-rich by Antarctic standards. Hard substratum samples taken within similar areas (about $4 \times 0.25$ square $\mathrm{m}$ ) at several depths at 5 sites along the Patagonia-Scotia ArcAntarctic Peninsula are reported in the current paper for the first time (see Gerdes et al., 1992 for a comparison of soft sediment and latitude within the Southern Ocean). Diversity was highest at the deeper depths $(12-35 \mathrm{~m})$ and patterns were similar both between sites and between the taxonomic levels used (Fig. 6). Thus higher taxon surrogacy for pattern analysis does seem valid for these data, albeit a 


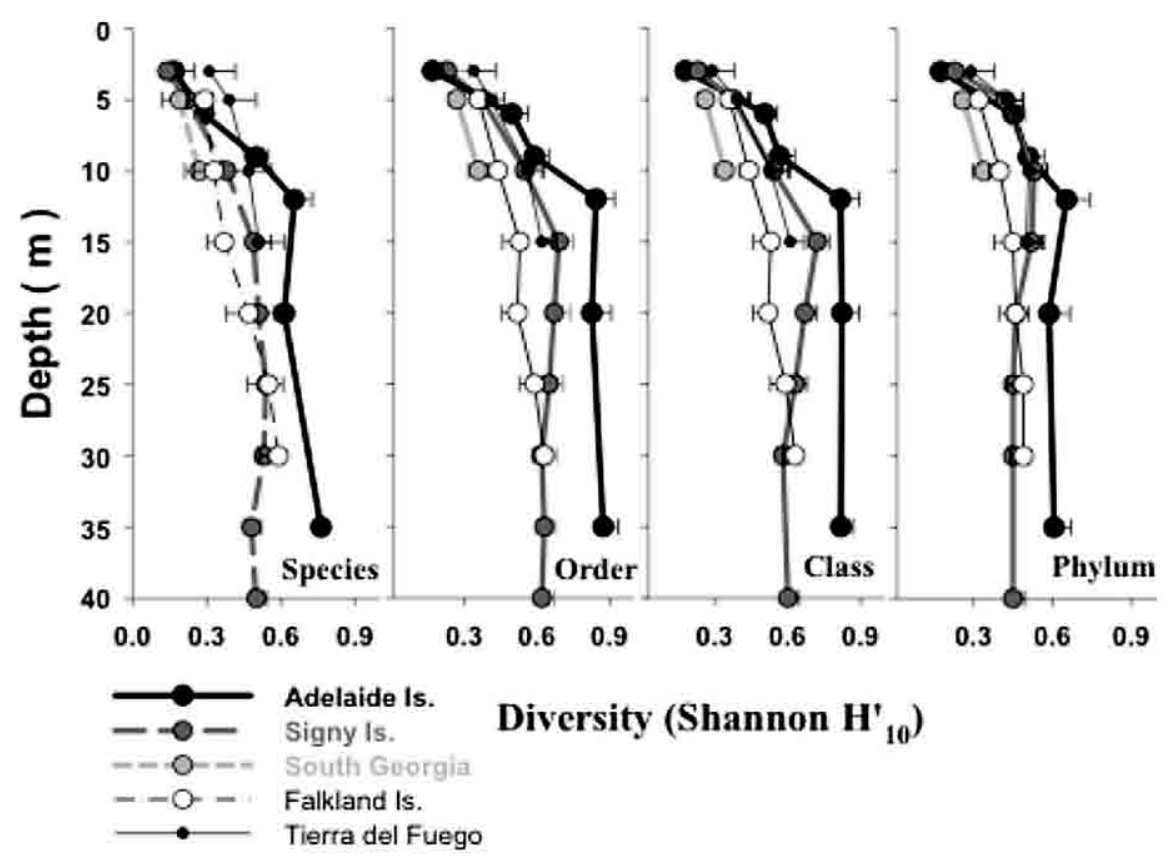

FIG. 6. - Benthic diversity (Shannon H' base 10) with site and depth in the Patagonia-Scotia Arc-Antarctic Peninsula region. South Georgia and Signy Is. occur in the Scotia Arc at $54^{\circ} \mathrm{S}$ and $60^{\circ} \mathrm{S}$ respectively, Adelaide Is. occurs at $68^{\circ} \mathrm{S}$ in the Antarctic Peninsula. Data from Barnes (1995b), Barnes and Brockington (2003) and author's unpublished collections.

small set. The lowest diversity (Shannon H') values were in the shallowest depths and in the Falkland/Malvinas and South Georgia. Thus, as with recruitment to settlement panels, low values are associated with isolated islands, but diversity at Signy Island, also in an isolated archipelago, was as high as at Tierra del Fuego.

Elsewhere in the world comparable methods have been used at similar, though northern latitudes. Maughan and Barnes (2000), in the subtidal zone of SW Ireland $\left(51^{\circ} \mathrm{N}\right)$, found uniformly fewer (range 10-67, mean 43) species at 3-18 m depth in mean sample areas of $2.747 \mathrm{~m}^{2}$. On the west Atlantic seaboard (Maine), Ojeda and Dearborn (1989) encountered just 60 species from sampling an area 14 times the size of the areas sampled here in the rocky subtidal. At a lower latitude, e.g. Milos Is., a site of established regional (Mediterranean Sea) benthic richness (Morri et al., 1999), numbers of hard substratum shallow benthic species were comparable with SW Ireland and lower than at Tierra del Fuego, Signy and Adelaide islands. In contrast, typical temperate and tropical species richness in the littoral zone is probably an order of magnitude higher (e.g. McGuiness, 1990; Maughan and Barnes, 2000). The taxon richness values at the PatagoniaScotia Arc-Antarctic Peninsula sites studied here are very high in comparison with typical Arctic sites (see Dayton, 1990; Arntz et al., 1994). Just 3-42 species $\mathrm{m}^{2}$ have been found at similar depths by a number of studies in the high Arctic from $10 \mathrm{x}$ the sample area (author's unpublished data, Holte et al., 1996; Sjer et al., 2000). There are, however, highly improverished subtidal faunas in the Scotia Arc and along the Antarctic Peninsula, such as the South Sandwich Islands and the wind- and wave-swept Snow Island (Barnes and Arnold, 2001a,b). At some isolated Subantarctic localities, such as Marion Island, considerable sublittoral species richness (64106 species in $0.4 \mathrm{~m}^{2}$ area, 203 species in $4 \mathrm{~m}^{2}$ ) has been reported (Becley and Branch, 1992). Although they are not completely barren, intertidal zone species richness and diversity on Antarctic shores is substantially reduced. In Tierra del Fuego, and to a lesser extent the Falkland/Malvinas, a wide range of animals and animal taxa are still common on sheltered shores. Pugh and Davenport (1997) did report a number of colonists on some littoral areas of South Georgia, but typically these shores have a very reduced presence of algae and animals. Further south, Rauschert (1991) and Barnes and Arnold (2001a,b) found 5 or fewer littoral species in large sample areas at Signy Island and various Antarctic Peninsula islands. Only at Thorgerson Is. (Palmer Archipelago) and Adelaide Island were as many as 9 littoral species found. The most common hard substratum species are generally the copepod Tigriopus angulatus, the limpet Nacella concinna, cheilostome bryozoans (e.g. Inversiula nutrix) and amphipods (e.g. Hippomedon kergueleni). On soft 
sediment shores (which are rare) amphipods and a variety of worms, such as sipunculans (e.g. Golfingia margaritacea) and priapulans (e.g. Priapulus tuberculatospinosus) are typical. The species richness of southern polar shores may be poor but most of them also represent different phyla. This mirrors the substantial higher taxon richness of the subtidal: 16 animal phyla and 25 classes were represented in $10 \mathrm{~m}^{2}$ at Adelaide Island. The combination of high space coverage, densities and richness in the subtidal zone and the fact that the system is almost certainly less complex than those at lower latitudes, should have made this region ideal for investigations of major ecological concepts such as competition for resources.

\section{COMPETITION}

It has long been thought that competition and predation are more severe with decreasing latitudes whilst environmental factors become more severe (see McGuiness, 1990). Such a difference between temperate and tropical regions has been hard to demonstrate because of confounding issues such as variability between sites, localities or regions and differences between taxa, basin ages and other variables. The vigourous research in polar regions has not yet, however, spread to competition in either polar marine realm. This may in part be due to the historical assertion that resources need to be limiting for competition to occur (Connell, 1978) and the assumption that in polar seas disturbance is high and empty space is common in young communities (Fig. 3E). However, many areas, such as cliffs, overhangs, crevices and caves are ice-sheltered, competition can be intense on assemblages a few years old (Fig. 3F) and there is virtually no free space on those unscoured for decades (Fig. 3D). In the ecological literature there is an abundance of studies in cool temperate North America and NW Europe. Much discussion has focused on the outcomes of competition, such as the importance of tied vs decided interactions (Schmidt and Warner, 1986), reversals in outcome between competitor pairs (Chornesky, 1989) and levels of transitivity (how hierarchical an assemblage is) (Russ, 1982; Tanaka and Nandakumar, 1994). How competition is structured on hard surfaces is of fundamental importance to recovery from disturbance and generation of diversity: in a strict hierarchy an ultimate dominant species should emerge and monopolise most space. This has been found to happen in a number of hard substratum environments. In such places diversity can be maintained either by mechanical or biological disturbance removing clumps of fauna and exposing space. Dayton (1971) found that floating logs smashed gaps in mussels which otherwise smothered the coast and Paine (1974) found that a keystone predator, Pisaster, acted similarly, opening up opportunities for competitive inferiors. This is equivalent to pioneer trees growing in the clearings made from the destructive fall of competitively superior trees. On Atlantic (Jackson, 1979) and Indo-West Pacific coral reefs (Chornesky, 1989), intransitive networks prevail in competition-resulting in so many ties or reversals in outcome that large numbers of species can exist side-by-side. Work in Patagonia (López Gappa, 1989), the Scotia Arc (Barnes and Arnold, 2001a) and the Antarctic Peninsula (Barnes and Clarke, 1998) showed that high latitude assemblages were more hierarchical than any other assemblages previously measured. The clashes between the encrusting animals of these southern polar communities rarely resulted in ties and the competitive dominant species overgrew any competitor encountered on virtually all occasions. Only in vertebrate intraspecific battles for status had such hierarchies previously been established (Clutton-Brock et al., 1979; Wagnon et al., 1996). There thus seems to be a latitudinal cline in the structure of competition, and therefore in the mechanism of succession in shallow marine environments (Barnes, 2002a). An obvious note of caution, though, is that there are comparatively few tropical data, so the low values of the few low latitude studies may be driving the significance of the relationship. The cline is still supported, though, even when just the southern polar data are examined (Fig. 7). The significance of this trend in competition as a

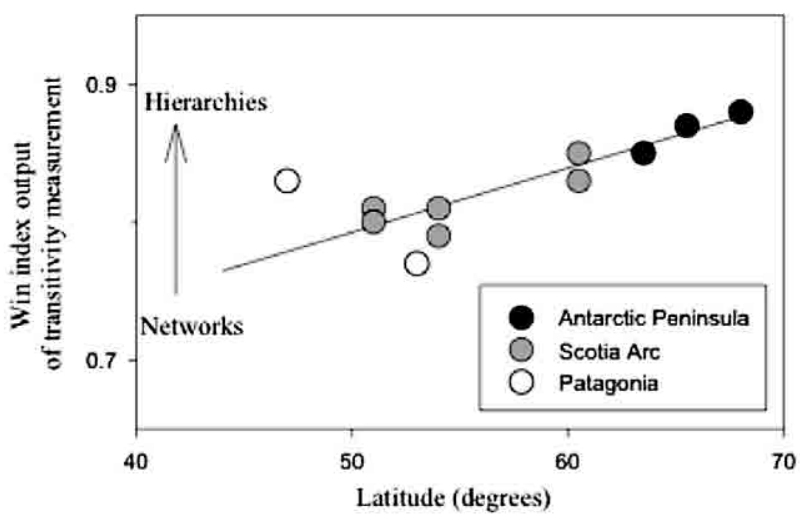

FIG. 7. - Change in assemblage transitivity (in encrusting benthos) with latitude in the Patagonia-Scotia Arc-Antarctic Peninsula region. $\mathrm{Y}$ axis is assemblage score on Tanaka and Nandakumar's (1994) index. Plot adapted from Barnes (2002a). 
structuring force is that typically in the tropics no environmental disturbance is required to maintain high levels of local diversity. At polar latitudes, in contrast, without disturbance, competitive dominants would monopolise vast areas of shallow benthic space (on hard substratum) and poorer competitors would be shut out completely. With current (high) levels of disturbance, diversity and richness is also low as assemblages are numerically dominated by fast growing pioneer species (Barnes and Clarke, 1998). Thus, with extremely high or low disturbance only one or two species prevail in an environment which at mid-levels (on the larger boulders, see Barnes et al., 1996) can support tens of species in just a square metre. As such, this system represents one of the best examples of the intermediate disturbance hypothesis (Connell, 1978; Huston, 1979) at local scales for hard substrata. Examples of poor competitors dominating assemblages are known from elsewhere in the world (Karlson, 1980; 1983; Paine, 1979), but in the Antarctic this phenomenon occurs along vast areas of hard bottom coastline. Therefore, although only small areas of space are occupied in very shallow waters around the Scotia Arc-Antarctic Peninsula, competition is common and severe. Only the regularity and catastrophic nature of disturbance enables pioneer species; the fast dispersers dominate what little space the fauna occupies. This 'rapid' colonisation of new space does involve adult movement as well as larvae recruiting into it, but speedy physical movement of animals in this entire region is unusual.

\section{METABOLISM AND ACTIVITY}

One of the most striking features of southern polar shallow water communities to an in situ observer is how little movement there is, despite (in places) high densities, biomass and richness. Sessile or sedentary suspension feeders and deposit feeders often comprise the major part of communities (see e.g. Gruzov and Pushkin, 1970; Winston and Heimberg, 1988; Gerdes et al., 1992; Barnes, 1995a) and are increasingly seen as playing a fundamental role in food webs (Gili and Coma, 1998). Even invertebrate predators such as nemertean worms, certain gastropods, pycnogonans and asteroids can still have moved less than a metre in a week. Greatly speeded up film has revealed some remarkable nemertean chases of limpets and burrowing and wriggling of bivalves over actual periods of many hours (Peck, pers. com.). The success of some fauna in such areas as polar seas and abyssal plains has been based on their living life in the slow lane (Emson, 1985). Certainly many of the highly successful fauna (e.g. bryozoans, brachiopods, echinoderms and hexactinellids [now placed in the phylum Symplasma]) are mainly bone and do not move or move only slowly. Even southern polar fish are usually fairly sluggish. They more than any other taxa have been important for larger scale comparisons of latitude and temperature on physiology such as muscle oxidative capacity (Johnston et al., 1998) and metabolic scaling (Clarke and Johnston, 1999). Again, the Scotia Arc and Antarctic Peninsula has been the focus for virtually all analysis of activity and metabolic rates, and how these link with environmental factors such as temperature. The normal oxygen consumption or resting metabolic rate has now been measured in quite a wide variety of animals (Fig. 8). Two decades ago almost nothing was known about the 'tick-over' of polar invertebrates but in the last two decades we have gained insight into oxygen use in a wide variety of taxa. Typical values stretch over approximately an order of magnitude $\left(30-300 \mu \mathrm{g} \mathrm{O}_{2} \cdot \mathrm{g} \mathrm{AFDM}^{-1} \cdot \mathrm{h}^{-1}\right)$ and seem to vary as much within as between taxa and lifestyles. For example, the highest and lowest values to date are both in sessile bryozoans. Though some of this work has been undertaken in places such as Kerguelen Island (Féral and Magniez, 1988), most has arisen from studies in the Scotia Arc and Antarctic Peninsula. When the values of these southern polar species in any group are compared with values for low latitude representatives (in those for which this comparison is possible), polar animals seem to have depressed metabolic rates but not metabolic cold adaptation (Peck, 1998; 2002).

Cold water does of course hold more gas than warm water, which in combination with great wave action and cold, dense surface water sinking means that southern polar waters are well oxygenated. After decades of argument and guesswork, oxygen availability has proved to be fundamentally linked to animal size (Chapelle and Peck, 1999). The idea of 'polar gigantism' inspired by huge isopods (e.g. Glyptonotus antarcticus) and pycnogonans (Decalopodium australis), amongst other animals, is simply an artefact of the high oxygen in cold polar waters. Predominantly Southern Ocean benthos such as molluscs, amphipods and isopods are small (see Hain, 1990; De Broyer and Jazdzewski, 1993; Brandt, 1999, respectively). Hain (1990) reports that 


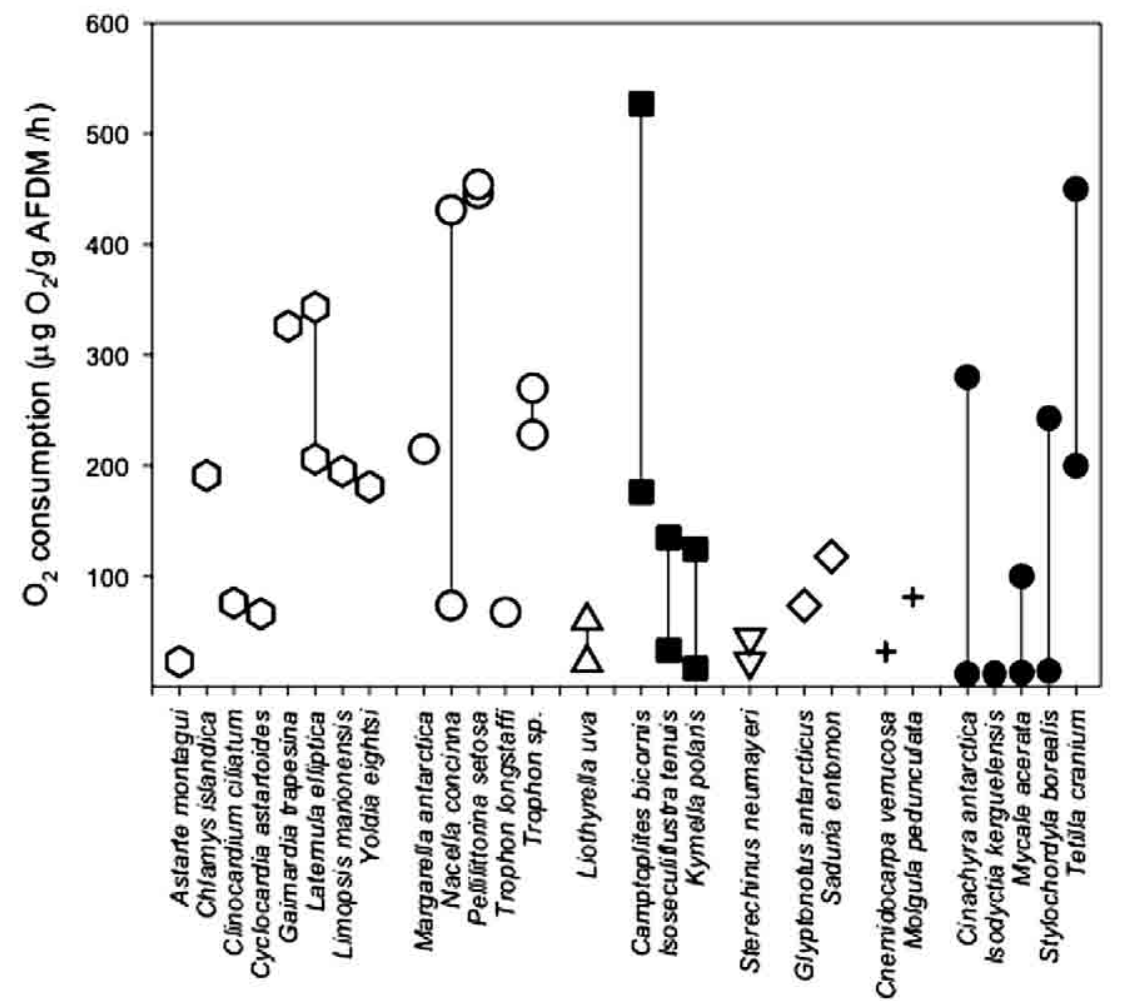

FIG. 8. - Mass-specific oxygen consumption measures $\left(\mu \mathrm{g} \mathrm{O}_{2} \cdot \mathrm{g}\right.$ AFDM $\left.{ }^{-1} \cdot \mathrm{h}^{-1}\right)$ in a range of polar marine invertebrates. The taxa are bivalves (hexagons), gastropods (open circles), a brachiopod (triangles up), bryozoans (filled squares), an echinoid (triangles down), isopods (diamonds), ascidians (crosses) and sponges (filled circles). Figure modified from Harper and Peck (2003) with data for bryozoans, echinoid, isopods, ascidians and sponges added. Data from Ralph and Maxwell (1977), Houlihan and Allan (1982), Davenport (1988), Schmid (1996), Peck et al. (1997), Ahn and Shim (1998), Pörtner et al. (1999), Gatti et al. (2000), Gatti and Orejas (2000), Brockington (2001), Kowalke et al. (2001), Robertson et al. (2001) and Peck and Barnes (2003). Lines show ranges of data for a given species.

$55 \%$ of molluscs are smaller than $10 \mathrm{~mm}$, for example. Nevertheless, because of the high oxygen levels in southern polar waters, giants occur. These include the largest bryozoan colonies and sponges $(1.5 \mathrm{~m}$ high or long), ctenophores (50 cm long) and nudibranch molluscs (30 cm long) (all pers. obs.). This strikes a strong contrast with not only the true terrestrial fauna, which are tiny (the largest are mites a few $\mathrm{mm}$ in size), but also typical animals in very shallow or deep waters. In the subtidal biota are so frequently hit by ice that populations are frequently formed of small (and young) individuals (Peck and Bullough, 1993; Urban and Campos, 1994; Barnes and Clarke, 1998; Urban and Mercuri, 1998; Brockington, 2001). The great size achieved in some taxa as a feature of this extreme environment was merely one of a number of major curiosities and themes of research into the growth of polar ectotherms.

\section{SEASONALITY OF FEEDING, GROWTH AND REPRODUCTION}

Investigations into feeding, growth and reproduction of polar invertebrates are necessarily also studies of seasonality. Seasonality is a major feature of shallow benthic communities across much of the globe and comparable responses of organisms can be seen in environments as seemingly dissimilar as the Mediterranean Sea and the Southern Ocean (Coma et al., 2000). The extreme nature of the light climate in the water column is further exaggerated by formation of sea-ice and overlying snow further decreasing light penetration in autumn or spring. Thus, abundant food availability to primary consumers is highly restricted to just a few months a year (Clarke, 1988). However, rather than all suspension feeders closing down and 'hibernating' for the majority of the year (see e.g. Gruzov, 1977), there is clearly a range of strategies varying from feeding for a couple of months to throughout the year (Barnes and Clarke, 1995). Feeding for long periods is possible in some taxa because they feed on the smaller nanophytoplankton (ciliates and flagellates), rather than the larger diatoms which dominate typical Southern Ocean blooms (Clarke and Leakey, 1996). Resuspension of particles, by currents or iceberg scouring, may also be important for non-summer feeding-benthic diatoms have, for example, been found in the stomachs of brachiopods 
during winter (Peck et al. unpublished data). As in several areas of ecology, in just a decade we have moved from a situation of almost no hard data to one in which we now have established the seasonal patterns of feeding for representatives from a wide variety of taxa. Even taxa traditionally regarded as difficult to examine feeding in, such as sponges and ascidians (see Gatti and Orejas, 2001; Kowalke, 1999; Tatián et al., 2002; Sahade et al., 2004 respectively), are beginning to be tackled. Typical seasonal patterns of plankton availability and feeding by a gastropod, an echinoid, an ascidian and a bryozoan are shown in Figure 9. Of course, nanoplanktonic food is not the dominant food for all of these or many other suspension feeders and the narrow feeding windows of some taxa, such as the holothurians (Barnes and Clarke, 1995), may be due to a reliance on the highly seasonal diatom abundance. One of

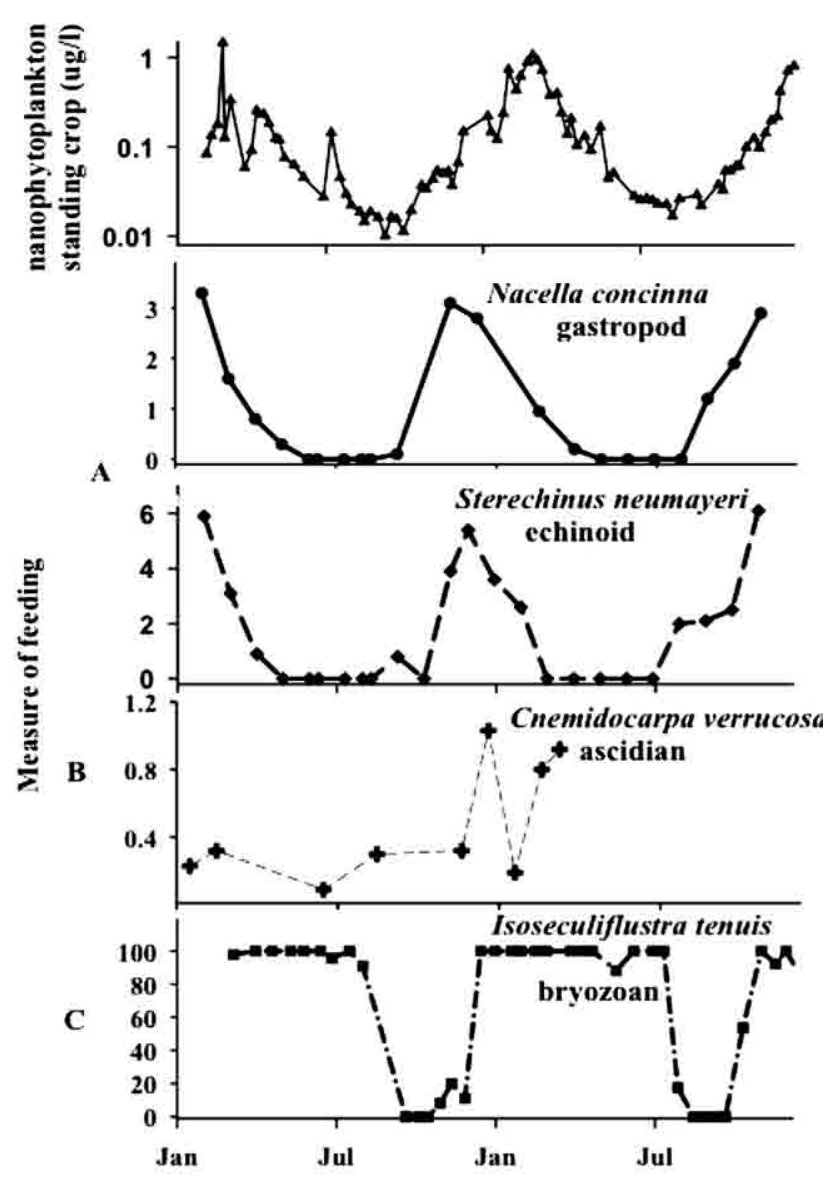

FIG. 9. - Seasonality of nanophytoplankton abundance and feeding activity of 4 primary consumers. The nano fraction is shown as an example of phytoplankton seasonality, and of the example species, nano phytoplankton is important food for $C$. verrucosa the ascidian and $I$. tenuis the bryozoan. In contrast $N$. concinna the limpet and $S$. neumayeri the echinoid feed on benthic material and larger particles. The axes are faecal egestion [faeces mg.individual dry mass $\left.(\mathrm{g})^{-1}\right](\mathrm{A})$, gut content dry mass.g (B) and per cent colonies feeding (C). Data are from Fraser et al. (2002), Brockington et al. (2001), Tatian et al. (2002) and Peck and Barnes (2003). the potential sources of food that we know little about and we should, perhaps, be making an effort to study is the bacterial picoplankton. Overall we probably now have good data for feeding of Antarctic suspension feeder communities and this has allowed comparisons between other areas for which there has been a large body of work, such as the Mediterranean Sea (Coma et al., 2000; Gili and Coma, 1998). They suggest strong similarities between tropical/subtropical and polar suspension feeders, which are predominantly feeding in clear waters in contrast to those in temperate regions with high particulate run-off even far from the coast.

In contrast to the work on feeding, which has focused on the Scotia Arc and Antarctic Peninsula (but see Gatti and Orejas, 2001), that on growth has been going on right round the Southern Ocean and is now one of the best known aspects of the Antarctic benthos (Arntz et al., 1994). Historically, much investigatory study has focused on fish (e.g. Wohlschlag, 1961; Burchett, 1983; Everson, 1984), due to obvious potential commercial applications, but here I will discuss progress on other taxa. Work on the duration, timing of initiation and cessation of feeding has helped interpret the patterns of growth, such as the establishment of growth check lines of some animals as annual (Barnes, 1995b). The production of growth check lines in taxa such as the molluscs (Lutz and Rhodes, 1980), bryozoans (Winston, 1983), brachiopods (Brey et al., 1995a) and echinoids (Brey et al., 1995b) is a major source of information. This provides not only the extent of annual growth (and so annual variability), age (and so variability with age) but also - by comparison to local primary productivity - relationships between the duration of food availability and growth. Use of stable isotopes has shown some high Antarctic bivalve, brachiopod and bryozoan growth check lines to be annual (Brey and Mackensen, 1997; Brey et al., 1999a,b). However, one the most common shallow water brachiopods produces growth check lines at a frequency of 1.8 years and has decoupled reproductive and somatic growth (Peck and Brey, 1996). These authors showed that shells of species, e.g. Liothyrella uva, living to great age are an environmental archive recording such events as atomic bomb tests decades ago. Most taxa do not, however, produce obvious 'readable' growth check lines. Early assessment of a taxon, the crustaceans, seemed to suggest slow growth (Littlepage, 1965; Oliver, 1979), which now seems to be typical for southern polar benthos (Arntz et al., 1994). It has 
TABLE 3. - Growth and reproductive tempo in benthic Antarctic animals in comparison with non-polar taxa. The symbols are Antarctic Peninsula (AP) and Scotia Arc (AC).

\begin{tabular}{|c|c|c|c|c|}
\hline taxon & growth tempo & reproduction & location & source \\
\hline sponges & slow, very few fast & & Ross Sea & $\begin{array}{l}\text { Dayton et al. } 1974 \text {, Dayton 1979, 1989; } \\
\text { Gatti et al. } 2002\end{array}$ \\
\hline cnidarians & & slow & Ross Sea & Oliver 1979, Orejas et al. 2002 \\
\hline nemerteans & & slow & SA, Ross Sea & Dearborn 1965, Peck 1993 \\
\hline annelids & & $\begin{array}{l}\text { highly diverse } \\
\text { strategies }\end{array}$ & Magellan Weddell Sea & Pearse et al. 1986, Gambi et al. 2000; 2001 \\
\hline crustaceans & slow & slow & $\begin{array}{l}\text { South Georgia, AP, } \\
\text { Ross Sea }\end{array}$ & $\begin{array}{l}\text { Littlepage 1965, Dearborn 1967, White 1970, } \\
\text { Oliver 1979, Luxmore 1982, Clarke 1985, } \\
\text { Marinovic 1987, Wägele 1987 }\end{array}$ \\
\hline molluscs & slow to very slow & slow & $\begin{array}{l}\text { SA, AP Macquarie Is } \\
\text { Ross Sea }\end{array}$ & $\begin{array}{l}\text { Shabica 1974, Ralph and Maxwell 1977, } \\
\text { Simpson 1977, Richardson 1979, Stockton 1984, } \\
\text { Berkmann 1990, Peck and Bullough 1993, Brêthes } \\
\text { et al. 1994, Urban and Mercuri 1998, Powell } 2001\end{array}$ \\
\hline brachiopods & slow to very slow & slow & SA, Weddell Sea & Brey et al. 1995a, Peck et al. 1997, Peck and Brey 1996 \\
\hline bryozoans & slow to comparable & slow & $\begin{array}{l}\text { AP, Patagonia, Ross Sea, } \\
\text { Weddell Sea }\end{array}$ & $\begin{array}{l}\text { Winston 1983, López Gappa 1989, Barnes 1995b, } \\
\text { Stanwell-Smith and Barnes 1997, Brey et al. } 1999 \text { a,b, } \\
\text { Barnes and Arnold 2001b, Cancino et al. } 2001\end{array}$ \\
\hline echinoderms & slow & slow & $\begin{array}{l}\text { SA, AP Kerguelen Is } \\
\text { Macquarie Is Ross Sea, } \\
\text { Weddell Sea }\end{array}$ & $\begin{array}{l}\text { Pearse 1965, Simpson 1982, Magniez 1983, } \\
\text { Yakovlev 1983, Bosch et al. 1987, McClintock and } \\
\text { Pearse 1987, McClintock et al. 1988, Pearse et al. } \\
\text { 1991, Gutt et al. 1992, Brey et al. 1995b }\end{array}$ \\
\hline ascidians & moderate - fast & & AP & $\begin{array}{l}\text { Rauschert 1991, Kühne 1997, Sahade et al. } 1998, \\
\text { Kowalke et al. 2001, Sahade } \text { et al. } 2004\end{array}$ \\
\hline fish & slow & slow & SA, AP, Antarctica & $\begin{array}{l}\text { Wohlschlag 1961, Burchett 1983, Everson 1984, di } \\
\text { Prisco et al. } 1991\end{array}$ \\
\hline
\end{tabular}

now been widely reported both that typical organic growth is slow and that there are exceptions (Dayton, 1989; Rauschert, 1991). Some Antarctic pioneer species have been reported as having tempos of growth which were 'fast' or comparable to low-latitude species (Barnes, 1995a; Dayton, 1989; Rauschert, 1991), but this is really only relative to typical temperate values. If the fastest polar species are compared with the fastest low-latitude species, i.e. pioneers compared with pioneers (like with like), growth seems universally slower in the polar realm. However, many polar animals are growing for only a short period, if the tempo of growth whilst actually growing is compared between polar and non-polar environments, growth may indeed be comparable (Barnes, 1995a). Here I would stress the importance of linking knowledge of precise food taken, its duration of abundance, feeding behaviour and allocation between somatic and reproductive development.

The tempo of reproduction, like growth, seems to be typically slow (Table 3 ). This is easiest seen in rates of larval development. Compared to temperate species echinoderms take up to 10x longer (Bosch et al., 1987; Hoegh-Guldberg and Pearse, 1995; Stanwell-Smith and Peck, 1998), bivalves take up to $15 \mathrm{x}$ longer (Powell, 2001) and brachiopods take up to 50x longer (Peck and Robinson, 1994). Again, like work establishing patterns of Antarctic invertebrate growth, reproductive strategies represent some of the earliest ecological work right around the shores of Antarctica. Even before the establishment of Thorson's rule (Mileikovsky, 1971), ecologists were intrigued by reproduction in cold water (Dearborn, 1965; 1967; Pearse, 1965). Several decades of study later, it remains true that molluscs have a high proportion of brooders and direct developing young and that some brooding taxa, such as the isopods, amphipods and pycnogonans, have achieved a high level of success (see Arntz et al., 1994 for general review). Pelagic larvae of many taxa have, in places, been found to be abundant in Antarctic waters and can be released into the water column at various times (Stanwell-Smith et al., 1998). Conversely, Arntz and Gili (2001) suggest that in comparison with temperate latitudes pelagic larvae are compara- 
tively rare in open-ocean areas south of the PFZ. There are certainly taxa that arguably (see Arntz and Gili, 2001) do not seem to follow Thorson's rule (Pearse et al., 1991) and on investigation some have a remarkable diversity of strategies (Gambi et al., $2000 ; 2001)$. One of the most important perspectives to emerge recently is the contrast between evolutionary vs ecological success of particular reproductive strategies. Amongst the echinoids, for example, most extant Antarctic shallow water species are brooders but the super-successful Echinidae are broadcast spawners (Poulin et al., 2002). Similarly amongst the molluscs, despite the prevalence of brooding, many of the most successful species (e.g. the limpet Nacella concinna) are also broadcast spawners with planktotrophic larvae. Poulin et al. suggest that this is due to selective extinction of those with pelagic larvae, probably during times when expanding ice sheets bulldozed fauna off the shelves into deeper water. Those pelagic spawners that did survive are much more able to quickly colonise shallow water environments, especially habitats with high rates of ice-scour disturbance where populations of adults are regularly destroyed. Alternatively, Pearse and Bosch (1994) argue that the nature of the circum-polar current might favour selective speciation of brooders (rather than selective extinction of broadcast spawners). There may be a middle ground between these ideas in which both selective extinction of broadcast spawners and selective speciation of brooders explains the current situation (Pearse and Lockhart, in press). The new emphasis on the importance of long-term data sets in marine biology is filtering through to the polar scientific community. Now that multiyear data sets exist for comparison of feeding, growth and reproductive patterns for a number of species, these could prove to be vital evidence in marine organism response to climate change.

\section{SEAS OF CHANGE}

Scientists across the world are quantifying all manner of changes in the biosphere at the current time, but then to our knowledge, many things have always been changing-it is the pace that differs. The large predators are disappearing from the world ocean environment to be replaced by man at the top of each food web (Jackson et al., 2001; Myers and Worm, 2003). Nowhere is this fishing depletion more obvious than in the Southern Ocean, where huge populations of the largest animals to ever populate the planet, the Balaenoptera whales, have been reduced to mere thousands of individuals (Roman and Palumbi, 2003). In terms of benthic habitats, though, those around the Antarctic continent must be amongst those least affected, as large vertebrates (such as teleost fish [though these can be major consumers of benthos], sharks, marine reptiles and mammals) have little structuring influence compared with elsewhere. Over the last century, when much of the fishing damage has been done, the earth's climate has warmed by about $0.6^{\circ} \mathrm{C}$. Across habitats there has been a major phenological (timing of activity) response from organisms, such as earlier flowering, migrant arrival and breeding (Walther $e t$ al., 2002). In the Arctic and west Antarctic, however, the temperature rise has - regionally at leastproved even more dramatic (Quadfasel et al., 1991). Both the highest increases of air temperatures (King and Harangozo, 1998) and lake temperatures (Quale et al., 2002) have been measured around the Scotia Arc-Antarctic Peninsula region. Quale et al. (2002) described this as nearly $1^{\circ} \mathrm{C}$ in the lakes of Signy Island in just a decade. The signal in the sea is not as clear and model estimates of $2^{\circ} \mathrm{C}$ change over the next 80 years have associated errors as large as the predicted values of change (Murphy and Mitchell, 1995). The rapid retreat and disintegration of ice shelves is suggested as a sign of drastic warming along coastal Antarctica (Doake and Vaughan, 1991). In just over half a century the ice shelf adjacent to the British Antarctic Survey Station of Rothera has retreated $2 \mathrm{~km}$ but the majority of this has occurred in just the last decade (Fig. 10). Similar retreats are being quantitatively marked in Patagonia and elsewhere in the world (though perhaps not in the high Antarctic). Considering that so many of the Southern Ocean's benthos is known to be highly stenothermal, they are an obvious group of organisms to act as indicators of biotic response. To have a massive effect on the biota, temperatures almost certainly do not need to rise to the point of killing animals through thermal shock but merely to functional limits whereby animals are not capable of feeding, reproducing or adequately defending themselves.

Generally associated biotic responses to changing temperatures are altitudinal and latitudinal range shifts, but also in the context of isolated Antarctic biota there is an increased possibility of invasions or survival of propagules. Unlike all other marine (and all terrestrial) environments, the Southern Ocean is 


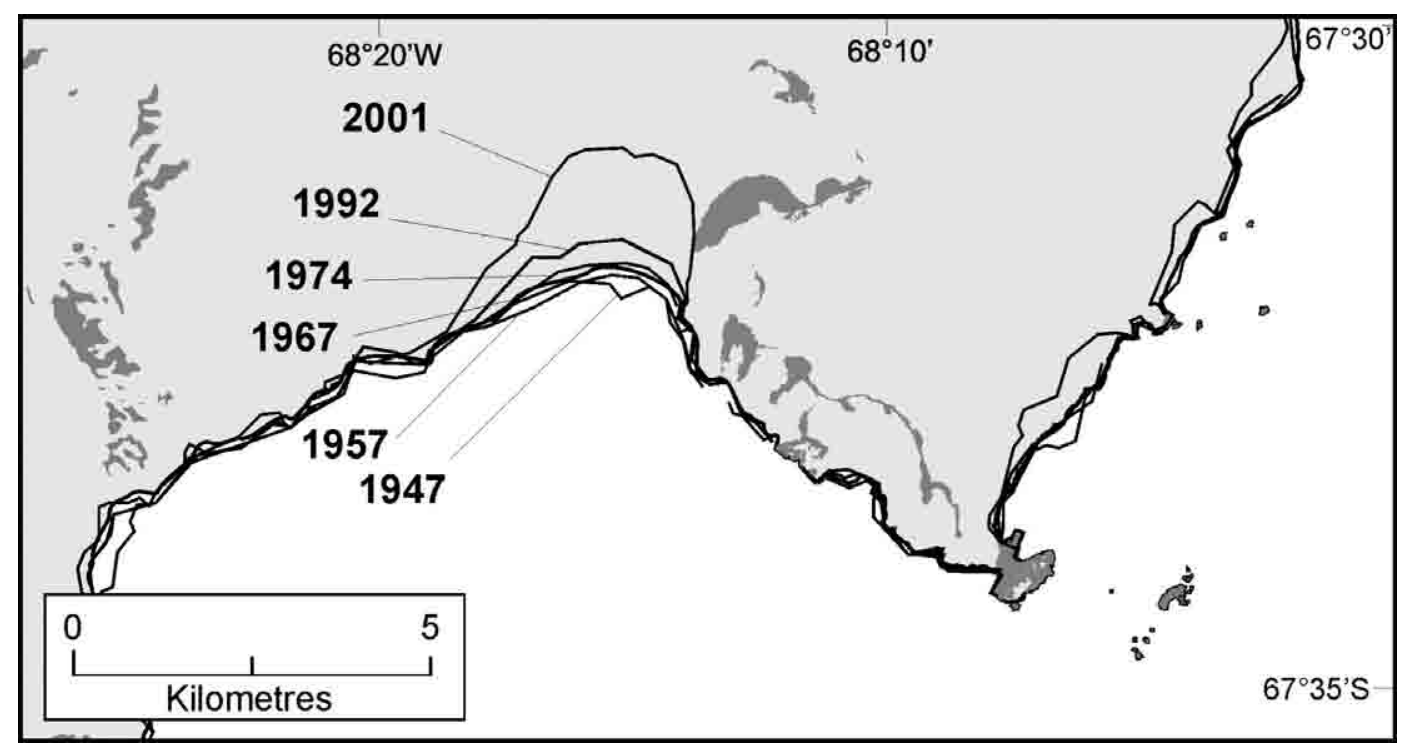

FIG. 10. - Coastline changes (ice sheet retreat) at Adelaide Island, Antarctic Peninsula over half a century. Data courtesy of Alison Cook (Mapping and Geographic Information Centre, BAS).

the only realm in which no invasive species are yet known. However, a few larvae of some decapod crustaceans and adults of others have recently been found around the South Shetland Islands (Thatje and Fuentes, 2003; and Tavares and Melo, 2004 respectively). Anomuran (lithodid) crabs, long known from South Georgia, are now present in deep water $(200+\mathrm{m})$ off the Antarctic Peninsula (Boschi and Gavio, 2003), though whether they have recently invaded this habitat or been there a while is unknown. In the Arctic lithodid crabs introduced to the Barents Sea have certainly undergone a major migration west across Subarctic Norway in just the last decade (Fletcher and Gollasch, 2003). It seems that it is only a matter of time before the first marine invaders establish a breeding population in the Southern Ocean. The region's best protection, sea temperatures barely above freezing in summer and nearly $-2^{\circ} \mathrm{C}$ in winter, may be on their way up if the predictions of the Hadley Centre model are born out (Murphy and Mitchell, 1995). We should be concerned, not only because Antarctic seas are the only ones left without known invaders but also because the fauna there has levels of endemism of $\sim 75$ 90\%-higher than anywhere else (Arntz et al., 1997). These values may appear very high partly because the Southern Ocean is big, and clearly the larger the area considered the higher its endemism (at $\mathrm{m}$ scale it is $\sim 0 \%$ and at global scale $100 \%$ ). Also, with increasing research some Antarctic species may have wider distributions, thus reducing the level of southern polar endemism. Nevertheless, it is likely that the real values of Antarctic endemism are indeed high. Endemics, frequently the species that are out-competed or eaten by introduced species, are gone forever if lost because, by definition, they occur nowhere else.

One of the most likely potential mechanisms of marine invasions is in ship ballast water or due to fouling hulls. Although shipping in general is not on the increase, those carrying scientists and particularly tourists to the Scotia Arc and Antarctic Peninsula regions certainly are. However, there is another source of transport to fouling organisms more numerous than ships, increasing faster and travelling to any shore: plastic debris. In the last two decades this has been increasing dramatically on even remote southern Atlantic islands (Ryan and Moloney, 1993) and reaching Southern Ocean islands before people have even set foot on them (Convey et al., 2002). By the early 1980s Subantarctic and Antarctic island shores right round the continent had plastics, tars and other debris washing up on them (Gregory et al., 1984; Torres and Gajardo, 1985; Ryan, 1987; Eriksson and Burton, 2001). Some of the longest data sets anywhere for the build-up of sea plastics are in the Scotia Arc-Antarctic Peninsula region (see e.g. Torres and Gajardo, 1985; Torres and Jorquera, 1996). With no longer any forests and only rare volcanic activity there are very few natural agents of flotsam within the Polar Frontal Zone, so the increase has been proportionally greater here than anywhere else. Of course, drifting macroalgae have probably been carrying float- 

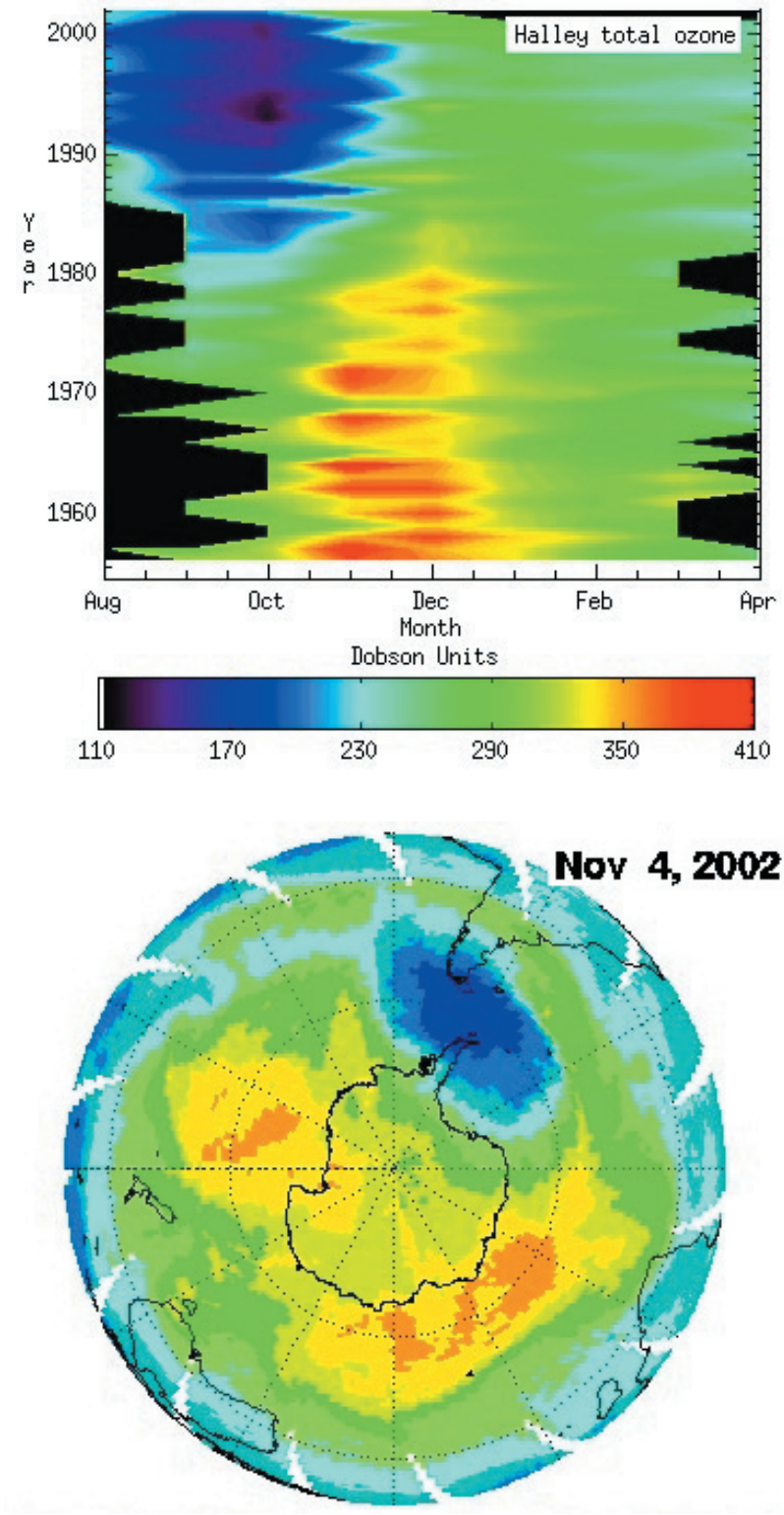

FIG. 11. - Stratospheric ozone changes with season and year, over nearly half a century, over the East Ronnie Ice Shelf (upper) and the geographic extent of the 'ozone hole' on Nov $4^{\text {th }}, 2002$. Data from Shanklin (2001) and NOAA.

ing biota for considerable periods of time, but they break down more quickly (in wave action or UV light), are now much rarer than artifacts, and many organisms preferentially settle on plastic (Barnes, 2002b). Just half a century ago plastics and other artefacts were rare at sea or on any islands; now it is rare for anywhere to be without them and a large proportion may carry attached biota (Barnes, 2002b). Recently just a single piece of floating plastic was found with 10 species from a total of 5 phyla washed onto an Adelaide Island shore, showing that, as in the tropics, diverse assemblages of animals can raft in the Southern Ocean (Barnes and Fraser,
2003). Worryingly, this seems to be an increasingly likely method of non-native species entering Antarctic waters, as the amount of material entering the seas keeps growing.

Production of waste has had another (though indirect), much better-known, influence on the polar regions: halogenated carbon molecules and other compounds of anthropogenic origin react in the stratosphere attacking ozone molecules. In the mid1980s large total losses of stratospheric ozone were discovered (Farman et al., 1985). The seasonal opening up of an 'ozone hole', which exposes organisms to higher doses of UV irradiation, has increased in intensity since its discovery (Fig. 11 upper). The area of depleted ozone is mobile and sometimes spans southern Patagonia to the northern Antarctic Peninsula (Fig. 11, lower). Penetration of UV into the water column is poor but is likely to have strong effects on the already fragile intertidal and shallow subtidal (Häder et al., 1998), and the impact on terrestrial ecosystems in the region and elsewhere has already been reported (Rozema, 1999; Newsham et al., 2002). The change from complete UV shielding to full exposure with retreat of snowpack in spring meltback is likely to be dramatic to the 'life on the edge' in the intertidal as it is to terrestrial organisms (Cockell et al., 2002).

\section{CONCLUSIONS}

The Patagonia-Scotia Arc-Antarctic Peninsula has proved to be an important place for scientific research in the last half century and particularly so in the last decade. The density of scientific stations is greater than anywhere else in Antarctica, as is the increase in the influence of man, most noticeably with the rapid rise of tourist vessels and marine flotsam. It seems to be a pivotal place for various aspects of climate change as well as studies on biogeography and biodiversity. Some of Antarctica's longest environmental data sets occur there and some of the key recent scientific advances in understanding scale, pattern and process in Southern Ocean benthic ecology have been made there. The sampling is patchy within this region but levels of knowledge are now approaching those for other shelf environments elsewhere in the world. There remain adjacent areas which are still very poorly known, however, like the Bellingshausen Sea. The next decade should see a strong push in expansion from predominantly organism and population work to work ranging from the subcellular level, through 
organism and populations, to ecosystems, with emphasis on the importance of each scale of evolution and ecology in Antarctica's benthos. We have some crucial questions to answer; many involve the past, such as when exactly did the Drake Passage open sufficiently for the circumpolar current to develop in deep water? As ice-shelves have started to retreat now can we interpret the patterns of colonisation with a view to explaining how recolonisation may have happened in the past? When ice-shelves expanded and bulldozed shallow faunas to the shelfedges (Clapperton and Sugden, 1988), were their refuge shelf areas that were not covered and can we link these periods in time to extinctions and subsequent radiations? Are larvae and/or adults crossing the Polar Frontal Zone regularly and are they doing so naturally or aided by man? How frequently do icebergs scour the seafloor and how does this change with depth and geography? How will sea temperature, circulation and ice-scour alter, and how will the biota react in the face of climate change? There are many questions to be answered and most will have a profound impact on our understanding of the world north of the PFZ. As just one example, the range of latitude covered by Patagonia, the Scotia Arc and the Antarctic Peninsula make it the only location for examining whether the northern diversity-latitude relationship really holds true in the southern hemisphere. Scientists in the Patagonia-Scotia ArcAntarctic Peninsula in the last 10 years have played a major role in shaping the concepts and current paradigms in benthic ecology - it will be important not to lose this momentum.

\section{DEDICATION}

The author would like to dedicate this paper to Kirsty Brown, who lost her life in July 2003 when attacked by a Leopard seal at the British Antarctic Survey's Rothera research station. She was undertaking cutting-edge work trying to measure how often and when ice actually scrapes the seabed. Kirsty was a dynamic, enthusiastic and extremely popular scientist with a bright future: she will be a big loss to the southern polar scientific community.

\section{REFERENCES}

Ahn, I.-Y. and J.H. Shim. - 1998. Summer metabolism of the Antarctic clam, Laternulaelliptica (King and Broderip) in Maxwell Bay, King George Island and its implications. J. Exp.
Mar. Biol. Ecol., 224: 253-264.

Allen, A.P., J.H. Brown and J.F. Gillooly. - 2002. Global biodiversity, biochemical kinetics, and the energetic-equivalence rule. Science, 297: 1545-1547.

Arnaud, P.M., C.M. López, I. Olaso, F. Ramil, A.A. Ramos-Esplá and A. Ramos. - 1998. Semi-quantitative study of macrobenthic fauna in the region of the South Shetland Islands and the Antarctic Peninsula. Polar Biol., 19: 160-166.

Arntz, W.E. and T. Brey. - 2003. The expedition ANTARKTIS XIX/5 (LAMPOS) of RV "Polarstern" in 2002. Ber. Polarforsch. Meeresforsch., 462: 1-120.

Arntz, W.E., T. Brey, and V.A. Gallardo. - 1994. Antarctic zoobenthos. Oceanogr. Mar. Biol. Ann. Rev., 32: 241-304.

Arntz, W.E., J. Gutt, and M. Klages. - 1997. Antarctic marine biodiversity: an overview. In: B. Battaglia (ed.) Antarctic communities: species, structure and survival, pp. 3-14. Cambridge University Press, Cambridge.

Arntz, W.E. and J.M. Gili. - 2001. A case for tolerance in marine ecology: let us not put out the baby with the bathwater. Sci. Mar., 65(Suppl. 2): 283-299.

Astorga, A., M. Fernández, E.E. Boschi and N. Lagos. - 2003. Two oceans, two taxa and one mode of development: latitudinal diversity patterns of South American crabs and test for possible causal processes. Ecol. Lett., 6: 420-427.

Baker, P.E., M.W. Holdgate, R.E. Longton, P.J. Tilbrook, J.F Tomblin, R.W. Vaughan and C.J.C. Wynne-Edwards. - 1964. A survey of the South Sandwich Islands. Nature, 203: 691-693.

Barnes, D.K.A. - 1995a. Sublittoral epifaunal communities at Signy Island, Antarctica. II. Below the icefoot zone. Mar. Biol., 121: 565-572.

Barnes, D.K.A. - 1995b. Seasonal and annual growth in erect species of Antarctic bryozoans. J. Exp. Mar. Biol. Ecol., 188: 181-198.

Barnes, D.K.A. - 1996. Low levels of colonisation in Antarctica: the role of bryozoans in early community development. In: D.P. Gordon, A.M. Smith and J.A. Grant-Mackie (eds.), Bryozoans in space and time, pp. 19-28. N.I.W.A., Wellington.

Barnes, D.K.A. - 2002a. Polarisation of competition increases with latitude. P. Roy. Soc. Lond. B, 1504: 2061-2069.

Barnes, D.K.A. - 2002b. Invasions by marine life on plastic debris. Nature, 416: 808-809.

Barnes, D.K.A. and R.J. Arnold. - 2001a. Competition, sublethal mortality and diversity on Southern Ocean coastal rock communities. Polar Biol., 24: 447-454.

Barnes, D.K.A. and R.J. Arnold. - 2001b. A growth cline in encrusting benthos along a latitudinal gradient within Antarctic waters. Mar. Ecol. Prog. Ser., 210: 85-91.

Barnes, D.K.A. and S. Brockington - 2003. Zoobenthic biodiversity, biomass and abundance at Adelaide Island, Antarctica. Mar. Ecol. Prog. Ser., 249: 145-155.

Barnes, D.K.A. and A. Clarke. - 1995. Seasonality of feeding activity in Antarctic suspension feeders. Polar Biol., 15: 335-340.

Barnes, D.K.A. and A. Clarke. - 1998. The ecology of an assemblage dominant: the encrusting bryozoan Fenestrulina rugula. Invertebr. Biol., 117: 331-340.

Barnes, D.K.A., P.J. Rothery and A. Clarke. - 1996. Colonisation and development in encrusting communities from the Antarctic intertidal and sublittoral. J. Exp. Mar. Biol. Ecol., 196: 251-265.

Barnes, D.K.A. and K.P.P. Fraser. - 2003. Rafting by five phyla on man-made flotsam in the Southern Ocean. Mar. Ecol. Prog. Ser., 262: 289-291.

Becley, L.E. and G.M. Branch. - 1992. A quantitative SCUBA diving survey of the sublittoral macrobenthos at Subantarctic Marion Island. Polar Biol., 11: 553-563.

Bentamy, A., N. Grima, Y. Quilfen, V. Harscoat, C. Maroni and S Pouliquen. - 1996. An atlas of surface wind from ERS-1 Scatterometer measurements. IFREMER publication, pp. 229, IFREMER, Plouzane, France.

Berkmann, P.A. - 1990. The population biology of the Antarctic scallop Adamussium colbecki (Smith 1902) at New Harbour, Ross Sea. In: K.R. Kerry and G. Hempel (eds.), Antarctic ecosystems: ecological change and conservation, pp. 281-288, Springer, Berlin.

Bolton, J.J. - 1983. Effects of short term ice scouring on a Newfoundland rocky shore community. Astarte, 12: 39-43.

Borkaw, N.V.L. - 1985. Treefalls, regrowth and community structure in tropical forests. In: S.T.A. Pickett and P.S. White (eds.), 
The ecology of natural disturbance and patch dynamics, pp. 5369. Academic Press, Orlando.

Bosch, I., K.A. Beauchamp, M.E. Steele and J.S. Pearse. - 1987. Development, metamorphosis and seasonal abundance of embryos and larvae of the Antarctic sea urchin Sterechinus neumayeri. Biol. Bull., 173: 126-135.

Boschi, E.E. - 2000. Species of decapod crustaceans and their distributions in the American marine zoogeographic provinces. Revista de Investigacion y Desarrollo Pesquero, 13: 1-136.

Boschi, E.E. and M.A. Gavio. - 2003. On the distribution of decapod crustaceans from the Magellanic Zoogeographic Province and the Antarctic Region. In: S. Thatje, J.A. Calcagno and W.E. Arntz. (eds.), Extended abstracts of the IBMANT/ANDEEP 2003, pp. 29-32. Ushuaia.

Brandt, A. - 1999. On the origin and evolution of Antarctic Peracarida (Crustacea, Malacostraca). Sci. Mar., 63 (Suppl. 1): 261-274.

Brêthes, J.-C., G. Ferreyra and S. de la Vega. - 1994. Distribution, growth and reproduction of the limpet Nacella (Patiginera) concinna (Strebel 1908) in relation to potential food availability, in Esperanza Bay (Antarctic Peninsula). Polar Biol., 14: 161-170.

Brey, T. and A. Clarke. - 1993. Population dynamics of marine benthic invertebrates in Antarctic and Subantarctic environments: are there unique adaptations? Antarct. Sci., 5: 253-266.

Brey, T., L.S. Peck, J. Gutt, S. Hain and W. Arntz. - 1995a. Population dynamics of Magellania fragilis, a brachiopod dominating a mixed-bottom macrobenthic assemblage on the Antarctic shelf. J. Mar. Biol. Ass. U.K. 75: 857-870

Brey, T., J.S. Pearse, L. Basch, J.B. McClintock and M. Slattery. 1995b. Growth and production of Sterechinus neumayeri (Echinoidea: Echinodermata) in McMurdo Sound, Antarctica. Mar. Biol., 124: 279-292.

Brey, T., D. Gerdes, J. Gutt, A. Mackensen and A. Starmans. 1999a. Growth and age of the Antarctic bryozoan Cellaria incula on the Weddell Sea shelf. Antarct. Sci., 11: 408-414.

Brey, T., J. Gutt, A. Mackensen and A. Starmans. - 1999b. Growth and productivity of the high Antarctic bryozoan Melicerita obliqua. Mar. Biol., 132: 327-333.

Brey, T. and A. Mackensen. - 1997. Stable isotopes prove shell growth bands in the Antarctic bivalve Laternula eliptica to be formed annually. Polar Biol., 17: 465-468.

Brockington, S. - 2001. The seasonal ecology and physiology of Sterechinus neumayeri (Echinodermata: Echinoidea) at Adelaide Island, Antarctica. $\mathrm{PhD}$ thesis, British Antarctic Survey, Cambridge.

Brockington S., A. Clarke and A.L.G. Chapman. - 2001. Seasonality of feeding and nutritional status during the austral winter in the Antarctic sea urchin Sterechinus neumayeri. Mar. Biol., 139: 1270-138.

Bromberg, S., E.F. Nonato, T.N. Corbisier and M.A.V. Petti. 2002. Polychaete distribution in the nearshore zone of Martel Inlet, Admiralty Bay (King George Island, Antarctica). Bull. Mar. Sci., 67: 175-188.

Burchett, M.S. - 1983. Age and growth of the Antarctic fish Notothenia rossii from South Georgia. Bull. Br. Antarct. Surv., 60: 45-61.

Cancino, J.M., F. Torres and H.I. Moyano. - 2001. Larval release pattern in Antarctic bryozoans. In: P.N. Wyse-Jackson, C.J. Buttler and M. Spencer-Jones (eds.), Bryozoan studies, pp. 6772. Balkema, Rotterdam.

Cattaneo-Vietti, R., M. Chiantore, M.C. Gambi, G. Albertelli, M. Cormaci and I. Di Geronimo. - 2000. Spatial and vertical distribution of benthic littoral communities in Terra Nova Bay. In: F.M. Faranda, L. Guglielmo and A. Ionora (eds.), Ross Sea Ecology, pp. 539-549. Springer, Berlin.

Chapelle, G. and L.S. Peck. - 1999. Polar gigantism dictated by oxygen availability. Nature, 399: 114-115

Chornesky, E.A. - 1989. Repeated reversals during spatial competition between corals. Ecology, 70: 843-855

Clapperton, C.M. and D.E. Sugden. - 1988. Holocene glacier fluctuations in South America and Antarctica. Quat. Sci. Rev., 7 : 185-198.

Clarke, A. - 1985. The reproductive biology of the polar hippolytid shrimp Chorismus antarcticus at South Georgia. In: J.S. Gray and M.E. Christiansen (eds.), Proc. $18^{\text {th }}$ Eur. Mar. Biol. Symp. pp. 237-245. John Wiley and Sons Ltd, New York.

Clarke, A. - 1988. Seasonality in the Antarctic marine environment. Comp. Biochem. Phys., 90B: 461-473.
Clarke, A. - 1992. Is there a latitudinal diversity cline in the sea? Trends Ecol. Evol, 7: 286-287.

Clarke, A. and N. Johnston. - 1999. Scaling of metabolic rate and temperature in teleost fish. J. Anim. Ecol., 68: 893-905.

Clarke, A. and N. Johnston. - 2003. Antarctic marine benthic diversity. Oceanogr. Mar. Biol. Ann. Rev., 41: 47-114.

Clarke, A. and R. Leakey. - 1996. The seasonal cycle of phytoplankton, macronutrients and microbial community in a nearshore Antarctic marine ecosystem. Limnol. Oceanogr., 41: $1281-1294$.

Clarke, A. and S. Lidgard. - 2000. Spatial patterns of diversity in the sea: bryozoan species richness in the North Atlantic. $J$. Anim. Ecol., 69: 799-814.

Clutton-Brock, T.H., S.D. Albon, R.M. Gibson and F.E. Guiness. 1979. The logical stag: adaptive aspects of fighting in Red dear (Cervus elaphus L.). Anim. Behav., 27: 211-225.

Cockell, C.S., G.P. Rettber, G. Horneck, D. Wynn-Williams, K. Scherer and A. Gugg-Helminger. - 2002. Influence of ice and snow covers on the UV exposure of terrestrial microbial communities: dosimetric studies. J. Photoch. Photobiol. B, 68: 23-32.

Collie, J.S., S.J. Hall, M.J. Kaiser and I.R. Poiner. - 2000. A quantitative analysis of fishing impacts on a shelf sea benthos. $J$. Anim. Ecol., 69: 785-798.

Collins, M.A., M. Belchier and I. Everson. - 2003. Why all the fuss about toothfish? Biologist, 50: 116-119.

Coma, R., M. Ribes, J.-M. Gili and M. Zabala. - 2000. Seasonality in coastal benthic ecosystems. Trends Ecol. Evol., 15: 448-453.

Conlan, K.E., H.S. Lenihan, R.G. Kvitek and J.S. Oliver. - 1998. Ice scour disturbance to benthic communities in the Canadian high Arctic. Mar. Ecol. Prog. Ser., 166: 1-16.

Connell, J.H. - 1978. Diversity in tropical rain forests and coral reefs. Science 199:1302-1310.

Convey, P., D.K.A. Barnes and A. Morton. - 2002. Artefact accumulation on Antarctic oceanic island shores. Polar Biol., 25: 612-617.

Crame, J.A. - 2000. Evolution of taxonomic gradients in the marine realm: evidence from the composition of recent bivalve faunas. Paleobiology, 26: 188-214.

Davenport, J. - 1988. Oxygen consumption and ventilation rate at low temperatures in the Antarctic Protobranch bivalve mollusc Yoldia (=Arquiyoldia) eightsi (Courthouy). Comp. Biochem. Physiol., 90A: 511-513.

Davenport, J. and T.D.I. Stevenson. - 1998. Intertidal colonization rates. A matched latitude, north $\mathrm{v}$ south, remote $\mathrm{v}$ near shore island experiment. Diversity Distributions, 4: 87-92.

Dayton, P.K. - 1971. Competition, disturbance and community organisation: the provision and subsequent utilisation of space in a rocky intertidal community. Ecol. Monogr., 41: 351-389.

Dayton, P.K. - 1979. Observations of growth, dispersal and dynamics of some sponges in McMurdo Sound, Antarctica, and its biological effects. In: Levian, C. and Bourny-Esnault (eds.) Sponge biology, pp. 271-283. Centre National de la Recherche Scientifique, Paris.

Dayton, P.K. - 1989. Interdecadal variation in an Antarctic sponge and its predators from oceanographic climate shifts. Science, 245: 1484-1486.

Dayton, P.K. - 1990. Polar benthos. In: W.O. Smith (ed.) Polar Oceanography, pp. 631-685. Academic Press, London.

Dayton, P.K. and R.R. Hessler. - 1972. Role of biological disturbance in maintaining diversity in the deep sea. Deep Sea Res., 19: 199-208.

Dayton, P.K., G.A. Robilliard and R.T. Paine. - 1970. Benthic faunal zonation as a result of anchor ice at McMurdo Sound, Antarctica. In: M.W. Holdgate (ed.) Antarctic Ecology, (Vol. 1) pp. 244257. Academic Press, London.

Dayton, P.K., G.A. Robilliard, R.T. Paine and L.B. Dayton. - 1974. Biological accommodation in the benthic community at McMurdo Sound, Antarctica. Ecol. Monogr., 44: 105-128.

De Broyer, C. and K. Jazdzewski. - 1993. Contribution to the marine biodiversity inventory. A checklist of the Amphipoda (Crustacea) of the Southern Ocean. Inst. R. Sci. Nat. Belg. Doc. Trav., 73: 1-154.

Dearborn, J.H. - 1965. Ecological and faunistic investigations of the marine benthos at McMurdo Sound, Antarctica. PhD thesis, Stanford University, California.

Dearborn, J.H. - 1967. Food and reproduction of Glyptonotus antarcticus (Crustacea: Isopoda) at McMurdo Sound, Antarctica. T. Roy. Soc. N.Z., 18: 163-168. 
DePalma, J.R. - 1969. Marine biofouling at Penobscot Bay, Maine, and Placentia Sound, Newfoundland, 1960 to 1968. Naval Oceanographic Office, Informal report, 69-56, Washington, USA.

Dionne, J.-C. - 1977. Relict iceberg furrows on the floor of Glacial Lake Ojibwa, Quebec and Ontario. Mar. Sed., 3: 79-81.

Doake, C.S.M. and D.G. Vaughan. - 1991. Rapid disintegration of the Wordie ice shelf in response to atmospheric warming. Nature, 350: 328-330.

Dowdswell, J.A., H. Villinger, R.J. Whittington and P. Marienfeld. - 1993. Iceberg scouring in Scoresby Sund and on the East Greenland continental shelf. Mar. Geol., 111: 37-53.

Ellis, D.V. and R.T. Wilce. - 1961. Arctic and subarctic examples of intertidal zonation. Arctic, 14: 224-235.

Emson, R. - 1985. Bone idle, a recipe for success? In: B.F. Keegan and B.D.S. O'Connor (eds.). Echinodermata, pp. 25-30. Rotterdam, Balkema.

Eriksson, C. and H. Burton. - 2001. Collections (1991 to 2000) of marine debris on Macquarie Island show increases in some fisheries-sourced materials. In: A. Huiskes (ed.) VIII SCAR Int. Biol. Symp., Abstract S6P07. Amsterdam.

Everson, I. - 1984. Fish Biology. In: R.M. Laws (ed.) Antarctic ecology II, pp. 491-532. Academic Press, London.

Farman J.C., B.G. Gardiner and J.D. Shanklin - 1985. Large losses of total ozone in Antarctica reveal seasonal $\mathrm{ClO}_{x} / \mathrm{No}_{x}$ interaction. Nature, 315: 207-210.

Féral, J.P. and P. Magniez. - 1988. Relationship between rate of oxygen consumption and somatic and gonadal size in the Subantarctic echinoid Abatus cordatus from Kerguelen. In: R.D. Burke, P.V. Mladenov, P. Lambert, and R.L. Parsley (eds.), Proc. $6^{\text {th }}$ Int. Echinoderm Conf. Balkema, Rotterdam.

Fletcher, N. and S. Gollasch. - 2003. Aliens invade the sea. I.C.E.S. newsletter, 40: 12-14.

Foster, M.W. - 1974. Recent Antarctic and Subantarctic brachiopods. Washington DC: American Geophysical Union. Antarctic Res. Ser., 21.

Fraser, K.P.P., A. Clarke and L.S. Peck. - 2002. Feast and famine in Antarctica: seasonal physiology in the limpet Nacella concinna. Mar. Ecol. Prog. Ser., 242: 169-177.

Fütterer, D.K., A. Brandt and G.C.B. Poore. - 2003. The expeditions ANTARKTIS XIX/3-4 of the research vessel POLARSTERN in 2002. Ber. Polarforsch. Meeresforsch., 470: $1-174$

Gallardo, V.A. - 1987. The sublittoral macrofaunal benthos of the Antarctic shelf. Envir. Int., 13: 71-81.

Gambi, M.C., M. Lorenti, F.R. Giovanni and M.B. Scipione. 1994. Benthic associations of the shallow hard bottoms off Terra Nova Bay, Ross Sea: zonation, biomass and population structure. Antarct. Sci, 6: 449-462.

Gambi, M.C., A. Giangrande and F.P. Patti. - 2000. Comparative observations on reproductive biology of four species of Perkinsiana (Polychaeta, Sabellidae). B. Mar. Sci., 67: 299-309.

Gambi, M.C., F.P. Patti, G. Micaletto and A. Giangrande. - 2001. Diversity of reproductive features in some Antarctic polynoid and sabellid polychaetes, with a description of Demonax polarsterni sp. nov. (Polychaeta: Sabellidae). Polar Biol., 24: 883-891.

Garwood, N.C., D.P. Janos and N. Brokaw. - 1979. Earthquake caused landslides: a major disturbance to tropical forests. Science, 205: 997-999.

Gatti, S. and C. Orejas. - 2001. Feeding and oxygen consumption: do they tell the same story about energetics of the Antarctic desmosponge Stylocordyla borealis? Poster, 37 European Marine Biology Symposium: A marine science odissey into the 21 st century, Menorca, Spain.

Gatti, S., T. Brey, W.E.G. Müller, O. Heilmayer and G. Holst. 2002. Oxygen microoptodes: a new tool for oxygen measurements in aquatic animal ecology. Ber. Polarforsch. Meeresforsch., 434: 37-57.

Gerdes, D., M. Klages, W.E. Arntz, R.L. Herman, J. Galerón and S. Hain. - 1992. Quantitative investigations on macrobenthos communities of the southeastern Weddell Sea shelf, based on multibox corer samples. Polar Biol., 12: 291-301.

Gili, J.M. and R. Coma. - 1998. Benthic suspension feeders: their paramount importance in littoral marine food webs. Trends Ecol. Evol., 13: 316-321.

Grassle, J.F. and H.L. Sanders. - 1973. Life histories and the role of disturbance. Deep Sea Res, 20: 643-659.
Gray, J.S. - 2001. Marine diversity: the paradigms in patterns of species richness examined. Sci. Mar., 65(Suppl. 2):41-56.

Gregory, M.R., R.M. Kirk and M.C.G. Mabin. - 1984. Pelagic tar, oil, plastics and other litter in surface waters of the New Zealand sector of the Southern Ocean and on Ross Dependency shores. N.Z. Antarct. Rec., 6: 12-28.

Gruzov, E.N. - 1977. Seasonal alterations in coastal communities in the Davis Sea. In: G. Llano (ed.) Adaptations within ecosystems, pp. 263-278. Smithsonian Press, Washington.

Gruzov, E.N. and A.F. Pushkin. - 1970. Bottom communities of the littoral region of the upper sublittoral of Enderby Land and the South Shetland Islands. In: M. Holdgate (ed.) Antarctic Ecology, pp. 235-238. Academic Press, London.

Gutt, J. - 2001. On the direct impact of ice on marine benthic communities, a review. Polar Biol., 24: 553-564.

Gutt, J., D. Gerdes and M. Klages. - 1992. Seasonality and spatial variability in the reproduction of two Antarctic holothurians (Echinodermata). Polar Biol., 11: 533-544.

Gutt, J. and D. Piepenburg. - 2003. Scale dependent impact on diversity of Antarctic benthos caused by grounding of icebergs. Mar. Ecol. Prog. Ser., 253: 77-83.

Gutt, J., A. Starmans and G. Dieckmann. - 1996. Impact of iceberg scouring on polar benthic habitats. Mar. Ecol. Prog. Ser., 137: 311-316.

Gutt, J. and A. Starmans. - 2001. Quantification of iceberg impact and benthic recolonisation patterns in the Weddell Sea (Antarctica). Polar Biol., 24: 615-619.

Häder, D.P., H.D. Kumar, R.C. Smith and R.C. Worrest. - 1998 Effects on aquatic ecosystems. J. Photoch. Photobiol. B, 46: 53-68.

Hain, S. - 1990. Die beschalten benthischen Mollusken (Gastropoda und Bivalvia) des Weddellmeeres, Antarktis. Ber. Polarforsch. Meeresforsch., 70: 1-181.

Harper, E. and L.S. Peck. - 2003. Feeding characteristics and metabolic costs in the Antarctic muricid gastropod Trophon longstaffi. Polar Biol., 26: 208-217.

Hayward, P.J. - 1995. Antarctic cheilostomatous Bryozoa. Oxford University Press, $355 \mathrm{pp}$

Hedgepeth, J.W. - 1969. Preliminary observations of life between tidemarks at Palmer station, $64^{\circ} 45^{\prime} \mathrm{S}, 64^{\circ} 05^{\prime} \mathrm{W}$. Antarct. J. U. S., 6: 160-162.

Hoegh-Guldberg, O. and J.S. Pearse. - 1995. Temperature, food availability, and the development of marine invertebrate larvae. Am. Zool., 35: 415-425.

Holdgate, M.W. and P.E. Baker. - 1979. The South Sandwich Islands: I. General description, Br. Antarct. Surv. Sci. Reports, 91: 1-76.

Holte, B., S. Dahle, B. Gulliksen and K. Naes. - 1996. Some macrofaunal effects of local pollution and glacier induced sedimentation, with indicative chemical analyses, in the sediments of two Arctic fjords. Polar Biol., 16: 549-557.

Holmes, N.J., V.J. Harriott and S.A. Banks. - 1997. Latitudinal variation in patterns of colonization of cryptic calcareous marine organisms. Mar. Ecol. Prog. Ser., 155: 103-113.

Houlihan, D.F. and D. Allan. - 1982. Oxygen consumption of some Antarctic and British gastropods and evaluation of cold adaptation. Comp. Biochem. Physiol., 73A: 383-387.

Hughes, T.P., A. H. Baird, E.A. Dinsdale, N.A. Moltschaniwskyj, M.S. Pratchett, J.E. Tanner, and B.L. Willis. - 1999. Patterns of recruitment and abundance along the Great Barrier Reef. Nature, 397: 59-63.

Huston, M. - 1979. A general hypothesis of species diversity. Am. Nat., 113: 81-101.

Jackson, J.B.C. - 1979. Overgrowth competition between encrusting cheilostome ectoprocts in a Jamaican cryptic reef environment. J. Anim. Ecol., 48: 805-823.

Jackson, J.B.C., M.X. Kirby, W.H. Berger, K.A. Bjorndal, L.W. Botsford, B.J. Bourque, R.H. Bradbury, R. Cooke, J. Erlandson, J.A. Estes, T.P. Hughes, S. Kidwell, C.B. Lange, H.S. Lenihan, J.M. Pandolfi, C.H. Peterson, R.S, Steneck, M.J. Tegner and R.R. Warner. - 2001. Historical overfishing and the recent collapse of coastal ecosystems. Science, 293: 629-638.

Jazdzewski, K. - 1998. Zoobenthos of Admiralty Bay, King George Island, South Shetland Islands. Pesquisa Antarctica Brasileira, 3: $1-7$.

Johnston, I.A., J. Calvo, H. Guderley, D. Fernandez and L. Palmer. - 1998. Latitudinal variation in the abundance and oxidative capacities of muscle mitochondria in perciform fishes. J. Exp. 
Biol., 201: 1-12.

Karlson, R.H. - 1980. Alternative competitive strategies in a periodically disturbed habitat. B. Mar. Sci., 30: 894-900.

Karlson, R.H. - 1983. Disturbance and monopolisation of a spatial resource by Zooanthus sociatus. B. Mar. Sci., 33: 118-131.

Kim, D.H. - 2001. Seasonal dynamics of an Antarctic rocky intertidal with emphasis on the role of the limpet Nacella concinna (Gastropoda: Patellidae). Ber. Polarforsch. Meeresforsch., 397.

King, J.C. and S.A. Harangozo. - 1998. Climate change in the western Antarctic Peninsula since 1945: observations and possible causes, Ann. Glaciol., 27: 571-575.

Kirkwood, J.M. and H.R. Burton. - 1988. Macrobenthic species assemblages in Ellis Fjord, Vestfold Hills, Antarctica. Mar. Biol., 97: 445-457.

Klöser, H., G. Ferreyra, I. Schloss, G. Mercuri, F, Laturnus and A. Curtosi - 1993. Seasonal variation of algal growth conditions in sheltered Antarctic bays: the example of Potter Cove (King George Island, South Shetlands). J. Mar. Syst., 4: 289-301.

Kowalke, J. - 1999. Filtration in ascidians - striking a balance. $J$. Exp. Mar. Biol. Ecol., 242: 233-244.

Kowalke, J., M. Tatián, R, Sahade and W.E. Arntz. - 2001. Production and respiration of Antarctic ascidians. Polar Biol., 24: 663-669.

Kühne, S. - 1997. Solitäre Ascidien in der Potter Cove (King George Island, Antarktis). Ihre ökologische Bedeutung und Populationsdynamik. Rep. Pol. Res., 252: 1-153.

Kvitek, R.G., K.E. Conlan and P.J. Iamietro. - 1998. Black pools of death: hypoxic, brine-filled ice gouge depressions become lethal traps for benthic organisms in a shallow Arctic embayment. Mar. Ecol. Prog. Ser., 162: 1-10.

Lee, H.J., S.Vanhove, L.S. Peck and M. Vincx - 2001a. Recolonisation of meiofauna after catastrophic iceberg scouring in shallow Antarctic sediments. Polar Biol., 24: 918-925.

Lee, H.J., D. Gerdes, S. Vanhove and M. Vincx. - 2001b. Meiofauna response to iceberg disturbance on the Antarctic continental shelf at Kapp Novegia (Weddell sea). Polar Biol., 24: 926-933.

Lien, R., A. Solheim, A. Elverhoi and K. Rokoengen. - 1989. Iceberg scouring and sea bed morphology on the eastern Weddell Sea shelf, Antarctica. Polar Res. 7: 43-57.

Littlepage, J.L. - 1965. Oceanographic investigations in McMurdo Sound, Antarctica. Antarct. Res. Ser. 5: 1-37.

López Gappa, J.J. - 1989. Overgrowth competition in an assemblage of encrusting bryozoans settled on artificial substrata. Mar. Ecol. Prog. Ser., 51: 121-130.

López Gappa, J.J. - 2000. Species richness of marine Bryozoa on the continental shelf and slope off Argentina (south west Atlantic). Diversity and Distributions 6: 15-27.

Lutz, R.A. and D.C. Rhodes. - 1980. Growth patterns within the molluscan shell: an overview. In: D.C. Rhodes and R.A. Lutz (eds.), Skeletal growth of aquatic organisms, pp. 203-254 Plenum Press, New York.

Magniez, P. - 1983. Reproductive cycle of the brooding echinoid Abatus cordatus (Echinodermata) in Kerguelen (Antarctic Ocean): changes in the organ indices, biochemical composition and caloric content of the gonads. Mar. Biol., 74: 55-64.

Marinovic, B.B. - 1987. The reproductive biology of the protogynous hermaphrodite Nototanais dimorphus (Beddard), an Antarctic tanaid. MSc thesis, University of California, Santa Cruz.

Maughan, B. and D.K.A. Barnes. - 2000. Epilithic boulder communities of Lough Hyne, Ireland: the influences of water movement and sediment. J. Mar. Biol. Ass. U.K., 80: 767-776.

McClintock, J.B. and J.S. Pearse. - 1987. Reproductive biology of the common Antarctic crinoid Promachocrinus kerguelensis (Echinodermata: Crinoidea). Mar. Biol., 96: 151-155.

McClintock, J.B., J.S. Pearse and I. Bosch. - 1988. Population structure and energetics of the shallow-water Antarctic sea star Odontaster validus in contrasting habitats. Mar. Biol., 99: 235-246

McCook, L.J. and A.R.O. Chapman. - 1997. Patterns and variations in natural succession following massive ice-scour of a rocky intertidal seashore. J. Exp. Mar. Biol. Ecol., 214:121-147.

McGuiness, K. - 1990. Physical variability, diversity gradients and the ecology of temperate and tropical reefs. Aust. J. Ecol., 15: $465-476$

Mileikovsky, S.A. - 1971. Types of larval development in marine bottom invertebrates, their distribution and ecological significance: a re-evaluation. Mar. Biol., 10:193-213.
Miller, K.A. and J.S. Pearse. - 1991. Ecological studies of seaweeds in McMurdo Sound, Antarctica. Am. Zool., 30: 35-48.

Morri, C., C.N. Bianchi, S. Cocito, A. Peirano, A.M. De Biase, S. Aliani, M. Pansini, M. Boyer, F. Ferdeghini, M. Pestarino and P. Dando - 1999. Biodiversity of marine sessile epifauna at an Aegean island subject to hydrothermal activity: Milos, eastern Mediterranean Sea. Mar. Biol., 135: 729-739.

Moyano, G.H.I. - 1984. On a small bryozoan collection from near Ross Island, Antarctica. Serie Científica Instituto Antárctico Chileno, 31: 75-83.

Murphy, E.J., A. Clarke, C. Simon and J. Priddle. - 1995. Temporal variation in Antarctic sea-ice: analysis of a long term fastice record from the South Orkney Islands. Deep-Sea Res. I, 42: 1045-1062.

Murphy, J.M. and J.F.B. Mitchell. - 1995. Transient response of the Hadley Centre coupled ocean-atmosphere model to increasing carbon dioxide. J. Climate, 8: 36-514.

Myers, R.A. and B. Worm. - 2003. Rapid worldwide depletion of predatory fish communities. Nature, 423: 280-283.

Nerini, M.K. and J.S. Oliver. - 1983. Gray Whales and the structure of the Bering Sea benthos. Oecologia, 59: 224-225.

Newsham, K.K., D.A. Hodgson, A.W.A. Murray, H.J. Peat and R.I.L. Smith. - 2002. Response of two Antarctic bryophytes to stratospheric ozone depletion. Glob. Change Biol., 8: 972-983.

Nonato, E.F., T.A.S. Brito, P.C. De Paiva, M.A.V. Petti and T.N. Corbisier. - 2000. Benthic megafauna of the nearshore zone of Martel Inlet (King George Island, South Shetland Islands, Antarctica): depth zonation and underwater observations. Polar Biol., 23: 580-588.

Ojeda, F.P. and J.H. Dearborn. - 1989. Community structure of macroinvertebrates inhabiting the rocky subtidal zone in the Gulf of Maine: seasonal and bathymetric distribution. Mar. Ecol. Prog. Ser., 57: 147-161.

Oliver, J.S. - 1979. Processes affecting the organisation of marine soft-bottom communities in Monterey Bay, California and McMurdo Sound, Antarctica. PhD thesis, University of California, San Diego.

Orejas, C., P.J. López-Gonzalez, J.-M. Gili, N. Teixidó, J. Gutt and W.E. Arntz. - 2002. Distribution and reproductive ecology of the Antarctic octocoral Ainigmaptilon antarcticum in the Weddell Sea. Mar. Ecol. Prog. Ser., 231: 101-114.

Paine, R.T. - 1974. Intertidal community structure: experimental studies on the relationship between a dominant competitor and its principal predator. Oecologia, 15: 710-719.

Paine, R.T. - 1979. Disaster, catastrophe, and local persistence of the sea palm Postelsia palmaeformis. Science, 205: 685-687.

Pearse, J.S. - 1965. Reproductive periodicities in several contrasting populations of Odontaster validus Koehler, a common Antarctic asteroid. Antarct. Res. Ser., 5: 39-85.

Pearse J.S. and I. Bosch. - 1994. Brooding in the Antarctic: Östergren had it nearly right. In: B. David, A. Guille, J.-P. Féral and M. Roux (eds.) Echinoderms through time, pp. 111-120. Balkema, Rotterdam.

Pearse J.S., I. Bosch, J.B. McClintock, B. Marinovic and R. Britton. - 1986. Contrasting tempos of reproduction by shallow water animals in McMurdo Sound, Antarctica. Antarct. J.U.S., 31: 182-184.

Pearse J.S. and S. Lockhart. - in press. Reproduction in cold water: Paradigm changes in the $20^{\text {th }}$ century and a role for cidaroid sea urchins. Deep-Sea Res.

Pearse J.S., McClintock, J.B. and I. Bosch. - 1991. Reproduction in Antarctic benthic marine invertebrates: tempos, modes and timing. Am. Zool., 31: 65-80.

Pearse J.S. and V. Pearse. - 1991. Year-long settlement panel study yields no Antarctic placozoans, and surprisingly little else. Antarct. J. U.S., 26: 149-150.

Peck, L.S. - 1993. Larval development in the Antarctic nemertean Parborlasia corrugatus (Heteronemertea, Lineidae). Mar. Biol., 116: 301-310.

Peck, L.S. - 1998. Feeding, metabolism and metabolic scope in Antarctic marine ectotherms. In: H.O. Pörtner and R.C. Playle (eds.), Cold Ocean Physiology. Cambridge University Press, Cambridge. Soc. Exp. Biol. Seminar Ser., 66: 365-390.

Peck, L.S. - 2002. Ecophysiology of Antarctic marine ectotherms: limits to life. Polar Biol., 25: 31-40.

Peck, L.S. and D.K.A. Barnes. - 2003. Metabolic flexability: the key to long-term ecological success in Bryozoa? P. Roy. Soc. Lond. B. (suppl.), 271: 18-21. 
Peck, L.S. and T. Brey - 1996. Bomb signals in old Antarctic brachiopods. Nature, 380: 207-208.

Peck, L.S., S. Brockington and T. Brey. - 1997. Growth and metabolism in the Antarctic brachiopod Liothyrella uva. Phil. Trans. Roy. Soc., 352: 851-858.

Peck, L.S., S. Brockington, S. Vanhove and M. Beghyn. - 1999. Community recovery following catastrophic iceberg impacts in Antarctica. Mar. Ecol. Prog. Ser., 186: 1-8.

Peck, L.S. and L.W. Bullough. - 1993. Growth and population structure in the infaunal bivalve Yoldia eightsi in relation to iceberg activity at Signy Island, Antarctica. Mar. Biol., 117: 235-241.

Peck, L.S. and K. Robinson. - 1994. Pelagic larval development in the brooding Antarctic brachiopod Liothyrella uva. Mar. Biol., 120: 279-286.

Pianka, E.R. - 1966. Latitudinal gradients in species diversity: A review of concepts. Am. Nat., 100: 33-46.

Pörtner, H.O., L.S. Peck, S. Zielinski and L.Z. Conway. - 1999. Intracellular $\mathrm{pH}$ and energy metabolism in the highly stenothermal Antarctic bivalve Limopsis marionensis as a function of ambient temperature. Polar Biol., 22: 17-30.

Pörtner, H.O. - 2002a. Physiological basis of temperature-dependent biogeography: trade-offs in muscle design and performance in polar ectotherms. J. Exp. Biol., 205: 2217-2230.

Pörtner, H.O. - 2002b. Environmental and functional limits to muscular exercise and body size in marine invertebrate athletes. Comp. Biochem. Physiol., 133: 303-321.

Pörtner, H.O. - 2002c. Climate variations and the physiological basis of temperature-dependent biogeography: systematic to molecular hierarchies of thermal tolerance in animals. Comp. Biochem. Physiol., 132A: 739-761.

Poulin, E., A.T. Palma and J.-P. Féral. - 2002. Evolutionary versus ecological success in Antarctic benthic invertebrates. Trends Ecol. Evol., 17: 218-222.

Powell, D. - 2001. The reproductive ecology of Antarctic freespawning molluscs. PhD thesis, University of Southampton, Southampton.

Di Prisco, G., B. Maresca and B. Tota. - 1991. Biology of Antarctic fish. Springer Verlag, Heidelberg.

Propp, M.V. - 1970. The study of bottom fauna at Haswell Islands by SCUBA diving. In: M. Holdgate (ed.), Antarctic Ecology, pp. 239-241. Academic Press, London.

Pugh, P.J.A. and J. Davenport. - 1997. Colonisation vs. disturbance: the effects of sustained ice-scouring on intertidal communities. J. Exp. Mar. Biol. Ecol., 210: 1-21, 1997.

Quadfasel, D., A. Sy, D. Wells and A. Tunik. - 1991. Warming in the Arctic. Nature, 350: 385

Quayle, W.C., L.S. Peck, C.J. Ellis-Evans, H.J. Peat and P.R. Harrigan. - 2002. Extreme responses to climate change in Antarctic lakes. Science, 295: 645.

Ralph, R. and J.H.G. Maxwell. - 1977. The oxygen consumption of the Antarctic limpet Nacella (Patinigera) concinna. Brit. Antarct. Surv. B., 45: 19-23.

Rauschert, M. - 1991. Ergebnisse der faunistischen Arbeiten im Benthal von King George Island (Südshetlandinseln, Antarktis). Ber. Polarforsch., 76: 1-75.

Rearic, D.M., P.W. Barnes and E. Reimnitz. - 1990. Bulldozing and resuspension of shallow-shelf sediment by ice keels: implications for Arctic sediment transport trajectories. Mar. Geol., 91: 133-147.

Richardson, M.G. - 1979. The ecology and reproduction of the brooding Antarctic bivalve Lissarca miliaris. Brit. Antarct. Surv. B., 49: 91-115.

Rivadeneira, M.M., M. Fernández and S.A. Navarrete. - 2002. Latitudinal trends of species diversity in rocky intertidal herbivore assemblages: spatial scale and the relationship between local and regional species richness. Mar. Ecol. Prog. Ser., 245: 123131.

Robertson, R.F., A.J. El-Haj, A. Clarke, L.S. Peck and E.W. Taylor. - 2001. The effects of temperature on metabolic rate and protein synthesis following a meal in the isopod Glyptonotus antarcticus Eights (1852). Polar Biol., 24: 677-686.

Roman, J. and S.R. Palumbi. - 2003. Whales before whaling in the North Atlantic. Science, 301: 508-510.

Roy, K., D. Jablonski, J.W. Valentine and G. Rosenberg. - 1998. Marine latitudinal diversity gradients: tests of causal hypotheses. P. Natl. Acad. Sci. USA, 95:3699-3702.

Rozema, J. - 1999. Stratospheric ozone depletion, the effects of enhanced UV-B radiation on terrestrial ecosystems, Backhuys, Leiden.

Russ, G.R. - 1982. Overgrowth in a marine epifaunal community: competitive hierarchies and competitive networks. Oecologia, 53: $12-19$.

Ryan, P.G. - 1987. The origin and fate of artefacts stranded at islands in the African sector of the Southern Ocean. Environ. Conserv., 14: 341-346.

Ryan, P.G. and C.L. Moloney. - 1993. Marine litter keeps increasing. Nature, 361: 23 .

Sahade, R., M. Tatian and G.B. Esnal. - 2004. Reproductive ecology of the ascidian Cnemidocarpa verrucosa at Potter Cove, South Shetland Islands, Antarctica. Mar. Ecol. Prog. Ser., 272: 131-140.

Sahade, R., M. Tatian, J. Kowalke, S. Kühne and G.B. Esnal. 1998. Benthic faunal associations on soft substrata at Potter Cove, South Shetland Islands, Antarctica. Polar Biol., 19: $85-91$

Santelices, B. and P.A. Marquet. - 1998. Seaweeds, latitudinal diversity patterns, and Rapoport's rule. Diversity and Distribution, 4: 71-75.

Schiavini, A., E. Frere, P. Gandini, N. Garcia and E. Crespo. 1998. Albatross-fisheries interactions in Patagonian shelf waters. In: G. Robertson and R. Gales (eds.), Albatross biology and conservation, pp. 208-213. Surrey, Beatty and Sons, Chipping Norton.

Schoener, A., E.R. Long and J.R. DePalma. - 1978. Geographic variation in artificial island colonisation curves. Ecology, 59: 367-382.

Schmid, M. - 1996. Oxygen consumption in Arctic marine invertebrates. Ber. Polarforsch. 94: 1-102.

Schmidt, G.H and G.F. Warner. - 1986. Spatial competition between colonial ascidians: the importance of stand-off. Mar Ecol. Prog. Ser., 31: 101-104.

Sejr, M.K., K.T. Jensen and S. Rysgaard. - 2000. Macrobenthic community structure in a high-Arctic East Greenland fjord. Polar Biol., 23: 792-801.

Shabica, S.V. - 1972. Tidal zone ecology at Palmer Station. Antarct. J. US, 7: 184-185.

Shabica, S.V. - 1974. Reproductive biology of the brooding Antarctic lamellibranch Kidderia subquadratum Pelseneer. MSc thesis, Oregon State University, USA.

Shanklin, J. - 2001. Back to basics: the ozone hole. Weather, 56 222-230.

Simpson, R.D. - 1977. The reproduction of some littoral molluscs from Macquarie Island (Subantarctic). Mar. Biol., 44: 125-142.

Simpson, R.D. - 1982. The reproduction of some echinoderms from MacQuarie Island. Australian Mus. Mem., 16: 39-52.

Skowronski, R.S.P., T.N. Corbosier and F.R. Robles. - 1998. Meiofauna along a coastal transect in Admiralty Bay, King George Island (Antarctica). Pesquisa Antarctica Brasileira, 3: 117-132.

Stanwell-Smith, D.P. and L.S. Peck. - 1998. Temperature and embryonic development in relation to spawning and field occurrence of larvae of 3 Antarctic echinoderms. Biol. Bull., 194: 44-52.

Stanwell-Smith, D. and D.K.A. Barnes. - 1997. Benthic community development in Antarctica: recruitment and growth on settlement panels at Signy Island. J. Exp. Mar. Biol. Ecol., 212: 61-79.

Stanwell-Smith, D., L.S. Peck, A. Clarke, A.W.A. Murray and C.D. Todd. - 1998. The distribution, abundance and seasonality of pelagic marine invertebrate larvae in the maritime Antarctic. Philos. Tr. R. Soc. Lond. B, 353: 1-14.

Stehli, F.G., A.L. McAlester and C.E. Helsey. - 1967. Taxonomic diversity of recent bivalves and some implications for geology. Geol. Soc. Am. Bull., 78: 455-466.

Stehli, F.G. and J.W. Wells. - 1971. Diversity and age patterns in hermatypic corals. Syst. Zool., 20: 115-126.

Stockton, W.L. - 1984. The biology and ecology of the epifaunal scallop Adamussium colbecki on the west side of McMurdo Sound, Antarctica. Mar. Biol., 78: 171-178.

Tanaka, M. and K. Nandakumar. - 1994. Measurement of the degree of intransitivity in a community of sessile organisms. $J$. Exp. Mar. Biol. Ecol., 182: 85-95.

Tatián, M., R. Sahade, J. Kowalke, S.C. Kivatinitz and G.B. Esnal. -2002 . Food availability and gut contents in the ascidian Cnemidocarpa verrucosa at Potter Cove, Antarctica. Polar Biol., 25: $58-64$. 
Tavares, M. and M.E.S. Melo. - 2004. No longer the last frontier: discovery of the North Atlantic spider crab Hyas araneus (Linneaus, 1758) in the Antarctic Peninsula. Antarct Sci., in press.

Thatje, S. and V. Fuentes. - 2003. First record of anomuran and brachyuran larvae (Crustacea: Decapoda) from Antarctic waters. Polar Biol., 26: 279-282.

Thrush, S.F. and P.K. Dayton. - 2002. Disturbance to marine benthic habitats by trawling and dredging: implications for marine biodiversity. Annu. Rev. Ecol. Syst., 33: 449-473.

Torres, D. and M. Gajardo. - 1985. Información preliminar sobre desechos plásticos hallados en Cabo Shirreff, Isla Livingston, Shetland del Sur. Bol. Antárt. Chileno, 5: 12-13.

Torres, D. and D. Jorquera. - 1996. Monitoring results of marine debris at Cape Shirreff, Livingston Island, South Shetland Islands, during the Antarctic season 1995/96. Ser. Cient. INACH, 46: 121-132.

Tucker, J.M. - 1988 Temporal distribution and brooding behaviour of selected benthic species from the shallow marine waters off the Vestfold Hills, Antarctica. Hydrobiologia, 165: 151-159.

Underwood, A.J. and S.J. Kennelly. - 1990. Ecology of marine algae on rocky shores and subtidal reefs in temperate Australia. Hydrobiologia, 192: 3-20.

Urban, H.-J. and B. Campos. - 1994. Population dynamics of the bivalves Gari solida, Semele solida and Protothaca thaca from a small bay in Chile at 36 ${ }^{\circ}$ S. Mar. Ecol. Prog. Ser., 115: 93-102.

Urban, H.-J. and G. Mercuri. - 1998. Population dynamics of the bivalve Laternula eliptica from Potter Cove, King George Island, South Shetland Islands. Antarct. Sci., 10: 153-160.

Valdovinos, C., S.A. Navarrete and P.A. Marqet. - 2003. Mollusk species diversity in the southern Pacific: why are there more species towards the pole? Ecography, 26: 139-144.

Vanhove, S., M. Beghyn, D. Van Gansbeke, L.W. Bullough and M. Vincx - 2000. A seasonally varying biotope at Signy Island, Antarctic: implications for meiofaunal structure. Mar. Ecol. Progr. Ser., 202: 13-25.

Vetter, R.A.H. and F. Buchholz. - 1998. Kinetics of enzymes in cold stenothermal invertebrates. Soc. Exp. Biol. Seminar Ser., 66: $190-211$

Villiers, A.F. de - 1976. Littoral ecology of Marion and Prince Edward islands (Southern Ocean). S. Afr. Tydskr. Antarkt. Nav., 1-40.
Vogt, P.R., K. Crane and E. Sundvor. - 1994. Deep Pleistocene iceberg plowmarks on the Yermak Plateau: sidescan and $3.5 \mathrm{kHz}$ evidence for thick calving ice fronts and a possible marine icesheet in the Arctic Ocean. Geology, 22, 403-406.

Wägele, J.-W. - 1987. On the reproductive biology of Ceratoserolis trilobitoides (Crustacea: Isopoda): Latitudinal variation of fecundity and embryonic development. Polar Biol., 7: 11-24.

Wagnon, K.A., R.G. Loy, W.C. Rollins and F.D. Carrol. - 1996. Social dominance in a herd of Angus, Hereford and shorthorn cows. Anim. Behav., 14: 474-479.

Walther, G.-R., E. Post, P. Convey, A. Menzel, C. Parmesan, T.J.C. Beebee, J.-M. Fromentin, O. Hoegh-Guldberg and F. Bairlein. - 2002. Ecological response to recent climate change. Nature, 416: 389-395.

Weslawski, J.M., J. Wiktor, M. Zajaczkowski and S. Swerpel. 1993. Intertidal zone of Svalbard 1. Macroorganism distribution and biomass. Polar Biol., 13: 73-79.

White, M.G. - 1970. Aspects of the breeding biology of Glyptonotus antarcticus (Eights) (Crustacea, Isopoda) at Signy Island, South Orkney Islands. In: M.W. Holdgate (ed.), Antarctic ecology Vol 1, pp. 279-285. Academic Press, London.

Winston, J.E. - 1983. Patterns of growth, reproduction and mortality in bryozoans from the Ross Sea, Antarctica. B. Mar. Sci., 33: 688-702.

Winston, J.E. and B.F. Heimberg. - 1988. The role of bryozoans in the benthic community at Low Island, Antarctica. Antarct. J. US, 21:188189.

Wohlschlag, D.E. - 1961. Growth of an Antarctic fish at freezing temperatures. Copeia, 1: 11-18.

Wulff, J.L. - 1995. Effects of a hurricane on survival and orientation of large erect coral reef sponges. Coral Reefs, 14: 55-61.

Yakovlev, S.N. - 1983. Reproductive cycle of Antarctic sea urchin Sterechinus neumayeri in Davis Sea. Sov. J. Mar. Biol., 9: $265-270$.

Zamorano, J.H. - 1983. Zonación y biomasa de la macrofauna bentónica en Bahía South, Archiépelago de Palmer, Antártica. INACH Ser. Cient., 30: 27-38.

Zieliñski, K. - 1981. Benthic macroalgae of Admiralty Bay (King George Island, South Shetland Islands) and circulation of algal matter between the water and the shore. Pol. Polar Res., 2: 71-94. 
